If 4. UNIYERSITY OF WASHINGTON DEPARTMENT OF

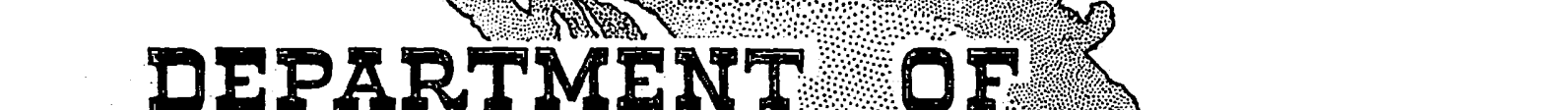

OCEANOGRAPHY

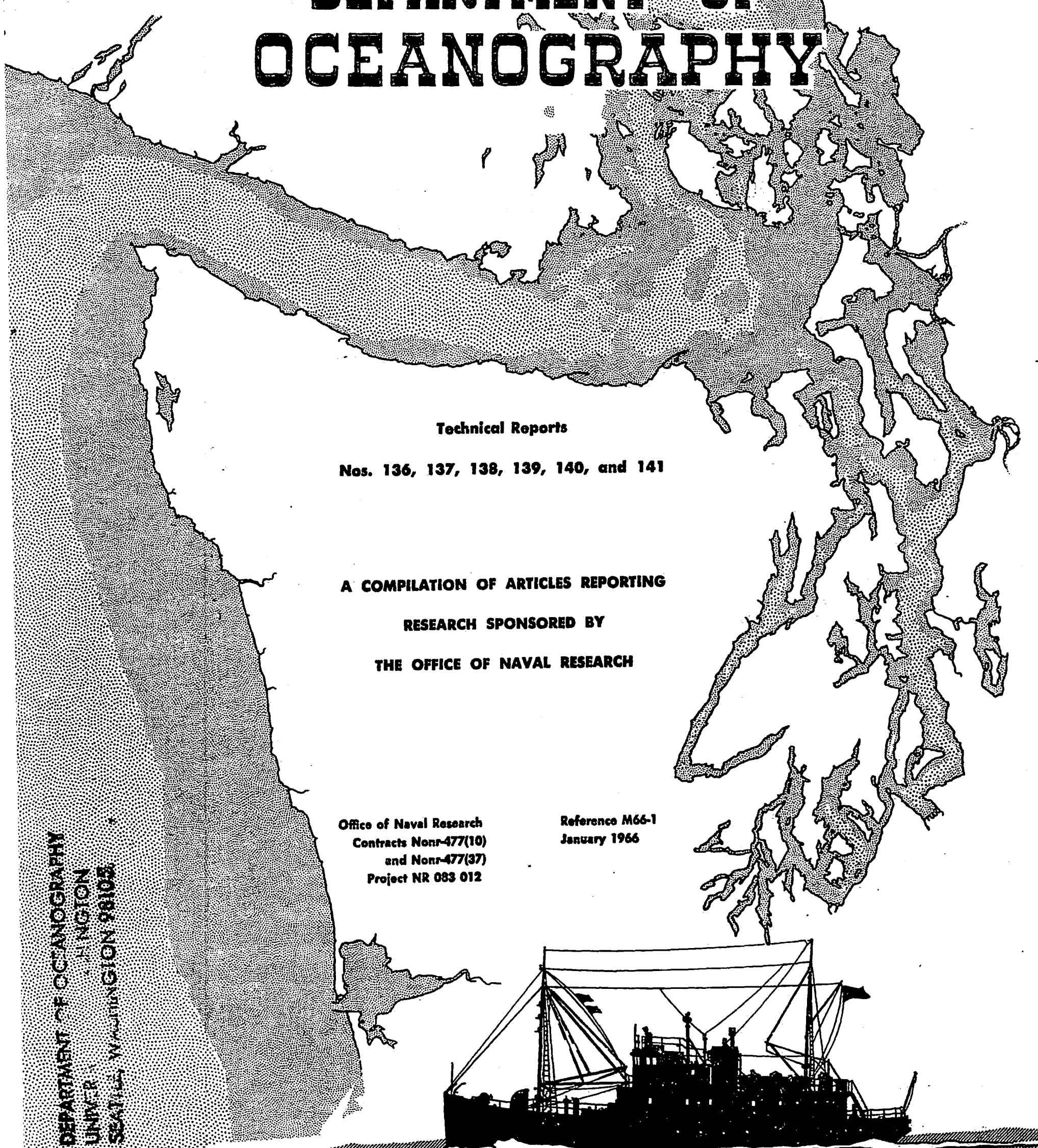


UNIVERSITY OF WASHINGTON

DEPARTMENT OF OCEANOGRAPHY

Seattle, Washington 98105

Technical Reports

Nos. 136, 137, 138, 139, 140, and 141

A COMPIIATION OF ARTICLES REPORTING

RESEARCH SPONSORED BY

THE OFFICE OF NAVAL RESEARCH

Office of Naval Research

Contracts Nonr-477(10)

Reference $\mathrm{M} 66 \mathrm{6}-1$

and Nonr-477(37)

Project NR 083012

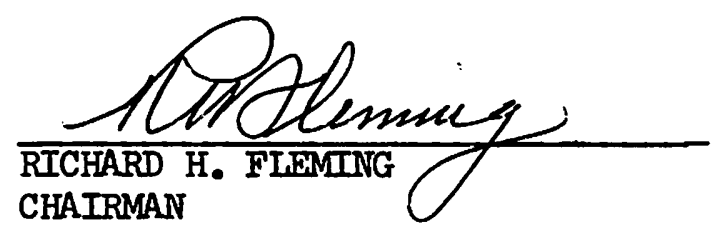

Reproduction in whole or in part is permitted for any purpose of the United States Government 
ARTICLES REPORTING RESEARCH SPONSORED BY THE OFFICE OF NAVAL RESEARCH

Technical Report No. 136

ON THE VERTICAL DISTRIBUTION OF ZOOPIANKTON IN THE SEA, by K. Banse. Pp. 55-125 in Progress in Oceanography, vol. II (Mary Sears, ed.). Pergamon Press, London. 1964.

Technical Report No. 137

SYNONYMS OF PROTODORVILLEA EGENA (EHLERS) (EUNICIDAE, POLYCHAETA), by K. Banse and G. Hartmann-Schrodder. Proceedings of the Biological society of Washington, 77:241-242. 30 December 1964.

$$
\text { Technical Report No. } 138
$$

THE INFLUENCE OF VARTABLE DEPIH ON STEADY ZONAL BAROIROPIC FLON, by Gene H. Porter and Maurice Rattray, Jr. Deutsche Hydrographische Zeitschrift, $17(4): 164-174$. 1964 .

Technical Report No. 139

THE MESOPEIAGIC CARIDEAN SHRIMP NOTOSTOMUS JAPONICUS BATE IN THE NORTHEASTERN PACIFIC, by Belle A. Stevens and Fenner A. Chace, Jr. Crustaceana, 8(pt. 3):277-284. 1965.

Technical Report No. 140

CARBONIFEROUS GIACIAL ROCKS FROM THE WERRIE BASIN, NEW SOUTH WALES, AUSTRAITA, by John T. Whetten. Geological Society of America Bulletin, 76:43-56. January 1965 .

Technical Report No. 141

THE ORIGIN OF MANGANESE NODULES ON THE OCEAN FLOOR, by Enrico Bonatti and Y. Rammohanroy Nayudu. American Journal of Science, 263:17-39. January 1965. 


\title{
THE ORIGIN OF MANGANESE NODULES ON THE OCEAN FLOOR $\dagger$
}

\author{
ENRICO BONATTI* and Y. RAMMOHANROY NAYUDU*
}

\author{
Scripps Institution of Oceanography, University of California, San Diego
}

\begin{abstract}
Ferromanganese oxide minerals are among the most common components of large areas of the ocean floor. Their chemical and mineralogical peculiarities have long stimulated considerable interest. A brief review of various theories on the origin of these minerals is presented.

Petrologic studies of some of the manganese nodules from the Pacific Ocean are reported, which show the existence in the nodules of a close association between ferro. manganese oxide phases and products of submarine volcanic effusions. Such an association can be explained admitting some genetical connection between deep-sea lava effusions and the nodules. These results, together with observations on their distribution and chemistry, do not seem to agree with the hypothesis which assumes a slow accretion of the nodules, owing to chemical deposition of manganese and related elements from normal sea water. It is instead suggested that the majority of manganese nodules from the Pacific Ocean bottom are formed as a consequence of submarine volcanism. Strong interaction between hot lavas and sea water takes place in many submarine volcanic effusions. As a result large quantities of iron, manganese, and other elements are leached out of the lava. Manganese is partially separated from iron, and the bulk of it is then precipitated on the ocean floor in the vicinity of the effusion, thus forming the nodules. Some geochemical implications of this hypothesis are also discussed briefly.
\end{abstract}

\section{INTRODUCTION}

Great concentrations of iron and manganese oxide minerals as concretions and crusts, and as fine particles dispersed in the sediment, are found in various areas of ocean floors. Since their discovery in the past century by Murray and Renard of the Challenger Expedition, there has been considerable interest in them. The unique chemical and mineralogical peculiarities of the so-called "manganese nodules" have been dealt with in many studies; reference to them may be found in Mero (1962) and Arrhenius (1963). There has been much speculation as to the origin and the mechanisms involved in the formation of these nodules. Detailed reviews of the various theories put forward can be found in H. Petterson (1945) and in Goldberg and Arrhenius (1958).

The literature shows two major groups of opinions about the origin of the manganese which is so richly concentrated in the nodules and in the associated sediments. One group holds that the principal source of the manganese is submarine volcanism; the other holds that most of the manganese is derived from sea water, that is, indirectly from the continents. The first author to suggest that ocean bottom manganese and iron are derived from local volcanics was Murray (Murray and Renard, 1891). His view was based on observations that the maganese nodules are often closely associated with volcanic materials. When later he was confronted with the fact that the $\mathrm{Mn} / \mathrm{Fe}$ ratio is much higher in the nodules than in the volcanics, he suggested that manganese might migrate upward from deeply buried strata and decomposing lavas, then be

$\dagger$ Contribution from Scripps Institution of Oceanography, New Series, and Contribution no. 336 of the Department of Oceanography, University of Washington.

* Present address: Institute of Marine Science, 1 Rickenbacker Causeway, Miami 49, Florida.

** Present address: Department of Oceanography, University of Washington, Seattle 5, Washington. 
precipitated in the oxidizing environment of the upper strata near the sedimentwater contact where the $\mathrm{Mn} / \mathrm{Fe}$ ratio would thus be greatly increased. In this view he was supported by Irvine (Murray and Irvine, 1895). Clarke (1924) also supported the volcanic origin of the manganese. More recently, Petterson (1945, 1959) favored the hypothesis that manganese is released from the submarine alteration of pyroclastics and from lava eruptions on the sea bottom.

The first authors to suggest continental rocks as principal source of the manganese (by means of weathering and oceanic transport) were Murray and Renard (1891). The supporters of this view mentioned various mechanisms that might account for the extraction of the manganese and iron from sea water through both biologic and inorganic agents. According to Correns (1941), manganese could possibly be extracted biologically from sea water by foraminifera, then concentrated at the bottom after the death of the organisms and the partial or total dissolution of their calcareous tests. However, Petterson (1945) convincingly showed that this process can in only very slight measure account for the high concentrations of manganese in the nodules and in some sediments. Other authors, such as Dorff (1935) and Graham (1959), suggested bacterial oxidation as the main extractive process. Graham showed the presence of organic matter in some nodules, but analyses of these substances by Degens (personal communication) have demonstrated the absence of peptide bonds between the amino acids which indicates that these were absorbed to the oxide minerals from sea water rather than synthesized by bacteria in the nodules.

Among the authors believing that inorganic reactions are responsible for the extraction of manganese from sea water, Kuenen (1950) thought that manganese is chemically precipitated in the deep sea, being thus greatly enriched in sediments with very low rates of deposition, such as the red clays. The objection to this hypothesis is that, since manganese presumably is undersaturated in sea water, a special mechanism would be required to accomplish its oxidation and precipitation at the sea bottom. Goldberg (1954) avoided this diffculty by postulating that manganese nodules are formed by electrophoretic deposition of colloidal particles of iron and manganese (which possess opposite electric charges) on any hard surface which would act as a natural electrode. Deep water movements, such as tides and currents, would provide the energy required for such a reaction. Goldberg also suggested that the more rare elements concentrated in the nodules, such as $\mathrm{Ni}, \mathrm{Cu}, \mathrm{Co}, \mathrm{Pb}, \mathrm{Zn}$, and some rare earths, are "scavenged" by the iron and manganese colloids from sea water. A few years later, Goldberg and Arrhenius (1958) revised this hypothesis because, among other reasons, most of the ocean-water manganese was found to be in solution and not in particulate form, and the current intensities obtained by tidal effects were too low to account for the accretion. Their interpretation of the process of formation of the iron and manganese concretions seems to be the one most widely accepted at present. It is as follows:

Manganous ions in solution in sea water would be oxidized to the tetravalent state by the catalytic action of iron oxide colloids near the oxygen-rich interface of sediment and water. The iron hydroxide deposited as a gel would provide the highly reactive surface necessary for the reactions. The manganese oxides so formed would associate with the catalyst and would become arranged 


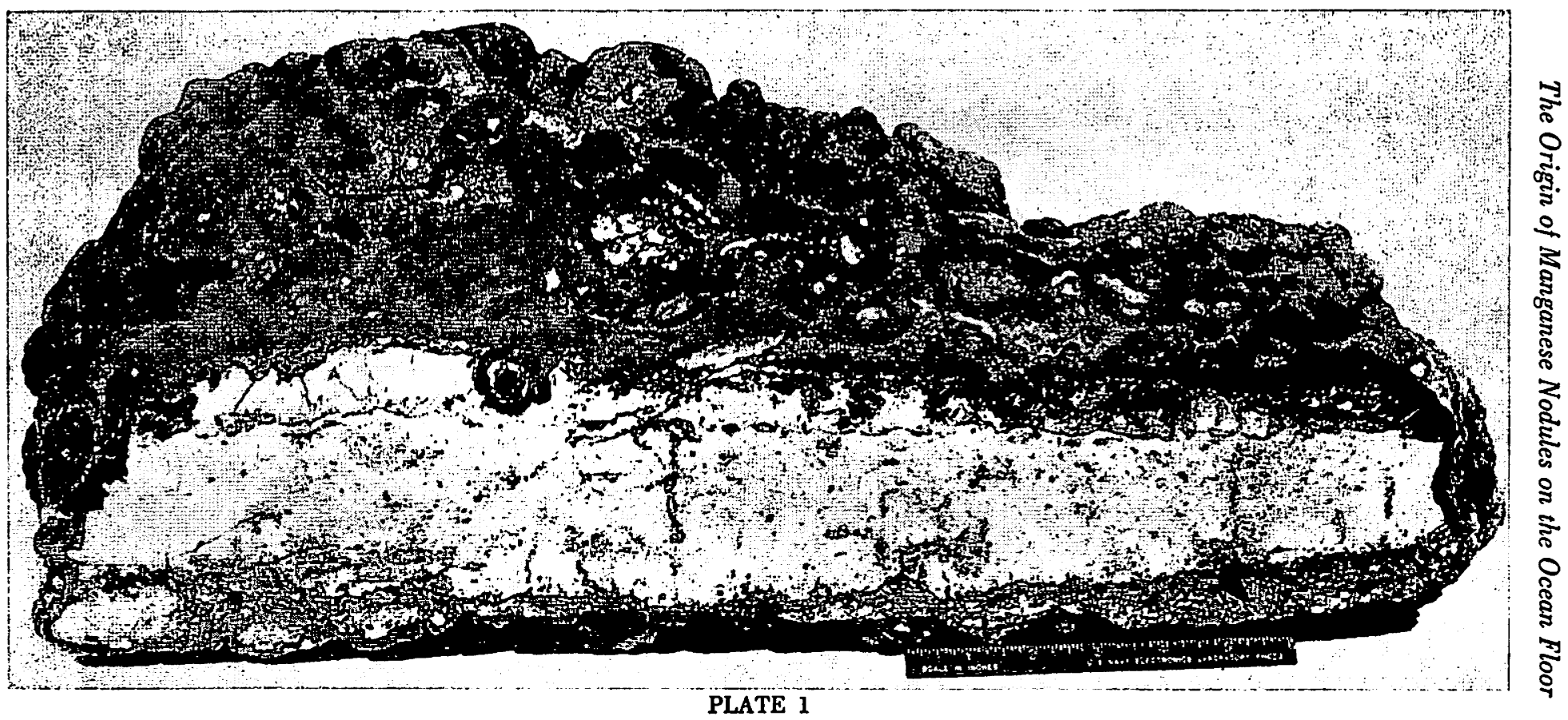

Cross section of the Horizon nodule from the North Pacific. Ferromanganese oxide minerals (dark) are associated with a light material consisting mainly of phillipsite. 
in the double layer structures reported by Buser and Grütter (1956) as typical of the nodules.

\section{OBSERVATIONS ON SOME NODULES FROM THE PACIFIC}

Results of microscopic and X-ray diffraction observations of some ferromanganese mineral samples recovered from various localities of the Pacific basin are reported here to provide some basic examples for the discussion which will follow.

\section{The "Ilorizon" Nodule from the North Pacific}

This specimen (pl. 1) was probably one of the most spectacular recoveries of its kind. It was collected at $40^{\circ} 14^{\prime} \mathrm{N}, 155^{\circ} 05^{\prime} \mathrm{W}$, under $5500 \mathrm{~m}$ of water. It weighs approximately $62 \mathrm{kgs}$, and its longer dimension is nearly $1 \mathrm{~m}$. It consists of a dark, thick mass of manganese and iron oxides enclosing a soft, light-colored material. This latter consists mainly of prismatic crystals of phillipsite only about $10.20 \mu$ in size, with minor quantities of yellowish grains, which probably are highly palagonitized glass. Under the microscope, some phillipsite crystals appear to be growing within palagonite grains in such fashion as to suggest that they developed from the palagonite. The association of the manganese and iron-oxide phases with the phillipsitic material shows interesting features; besides the large zeolitic core, phillipsite is also scattered as small aggregates in the oxide phases (pl. 2-A). Material in some cavities of the external surface of the nodule and in a fissure extending into its interior was analyzed by X-ray powder diffraction. Its main components were found to be quartz, feldspar, muscovite, and chlorite. These are the terrigenous minerals normally constituting the sediments at present being deposited in this area of the North Pacific Ocean floor (Arrhenius and Bonatti, in preparation).

\section{Manganese nodules from the Mendocino Ridge}

Several manganese nodules and boulders of basalt were dredged from the top of the Mendocino Ridge, in the Northeast Pacific, during the Scripps Institution of Oceanography expedition Fanfare. The sample under description (Fan $25 \mathrm{BD}$ ) was obtained at a water depth of $1260 \mathrm{~m}$, at lat $40^{\circ} 23^{\prime} \mathrm{N}$ and long $127^{\circ} 59^{\prime} \mathrm{W}$. The handspecimen shows a dark brown crust of manganese and iron oxides with protruding fragments of basalt. Within the crust, yellowish brown patches are visible. The interior of this nodule has the appearance of a palagonite tuff or "hyaloclastite" ( $\mathrm{pl}$. 3-A). The outer rim of the interior consists of fragments of fine-grained, compact basalt of various shapes and sizes, enclosed in a yellowish-gray matrix. Toward the core of this nodule bright yellow palagonitic material occurs as matrix, enclosing fragments of fine sand-size black glass (sideromelane).

In thin section, the fragments of basalt of the outer rim show the presence of aggregates of fresh labradorite in the form of needles and fine laths. Pyroxenes and olivine, along with basaltic glass, form the interstitial material. Both pyroxenes and olivine show little or no alteration, whereas the glass of the base is loaded with bundles of needles and rods of opaque oxides, which show a tendency to concentrate along the margins of the fragments. The matrix for 
PLATE 2

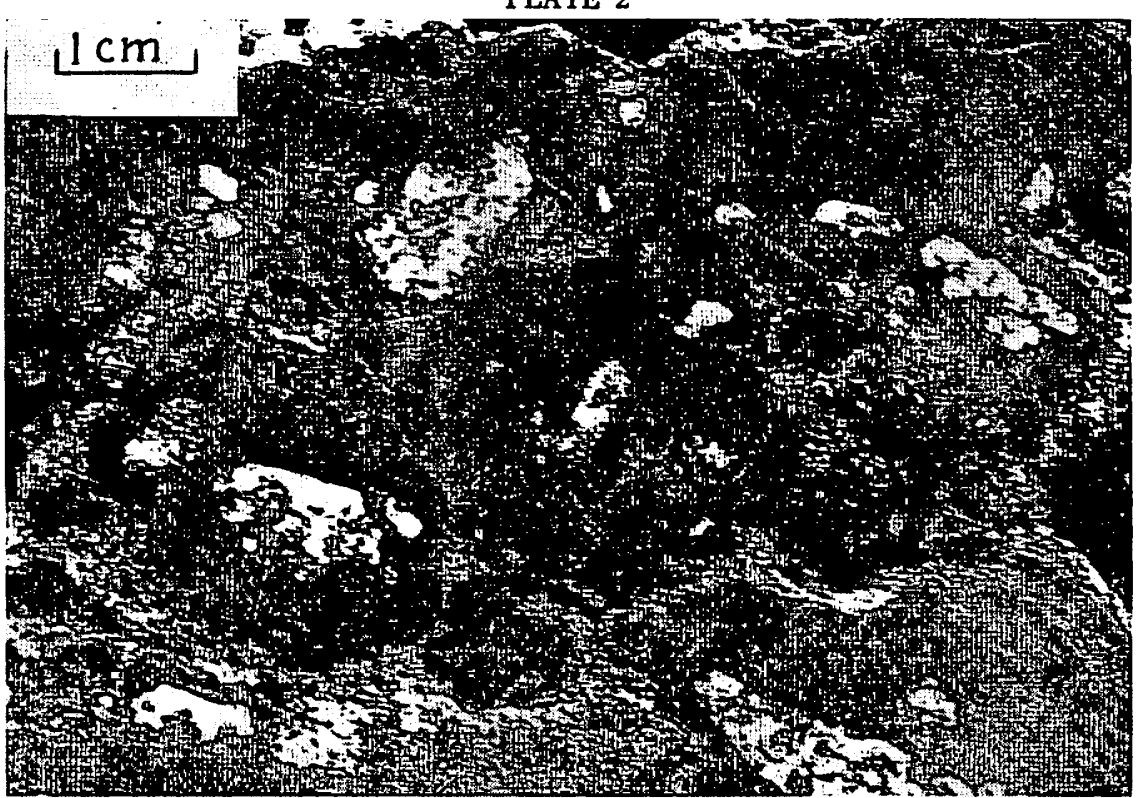

A. Close-up view of a portion of the Horizon nodule, showing white patches of phillipsite scattered in the thick crust of ferromanganese oxides.

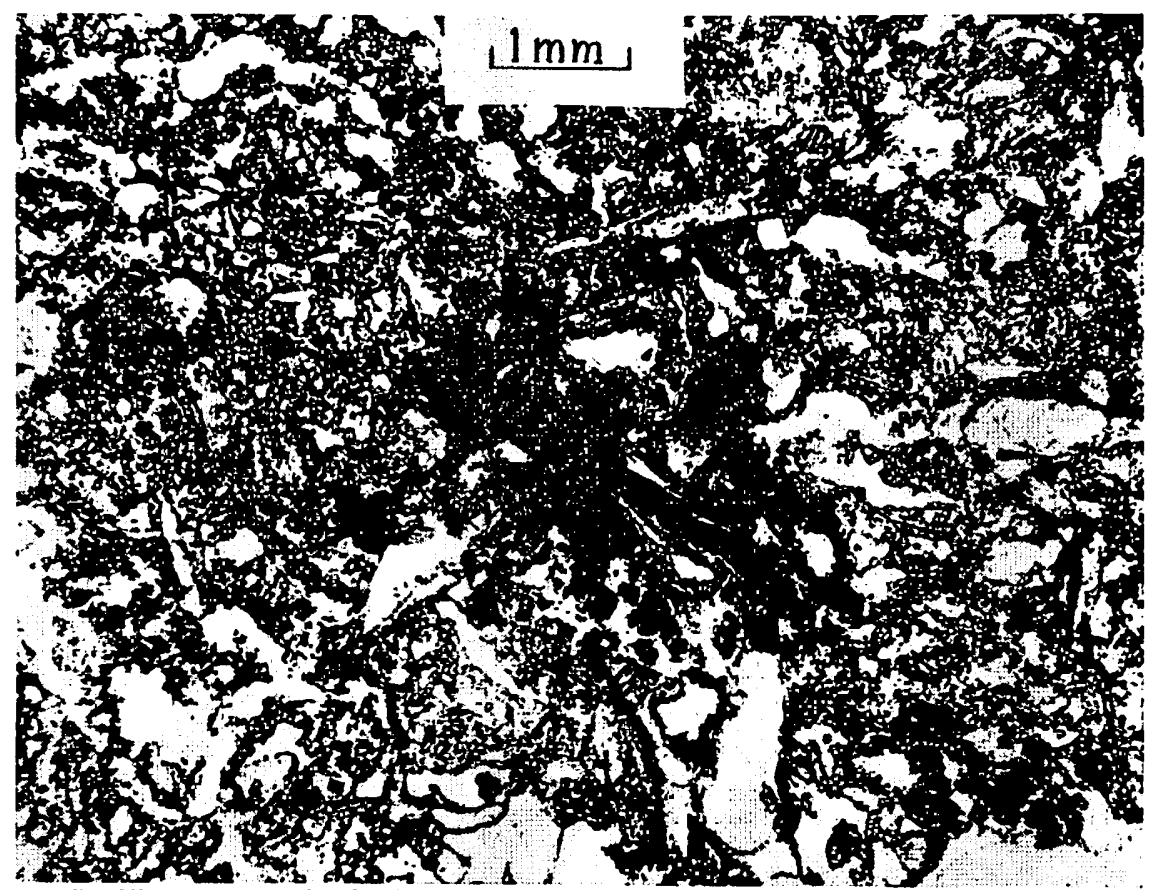

B. Thin section of a hyaloclastite fragment from the Southeast Pacific, showing fer. romanganese oxide segregations (black) within the sideromelane-palagonite rock. Similar segregations are scattered throughout the rock. 
PLATE 3

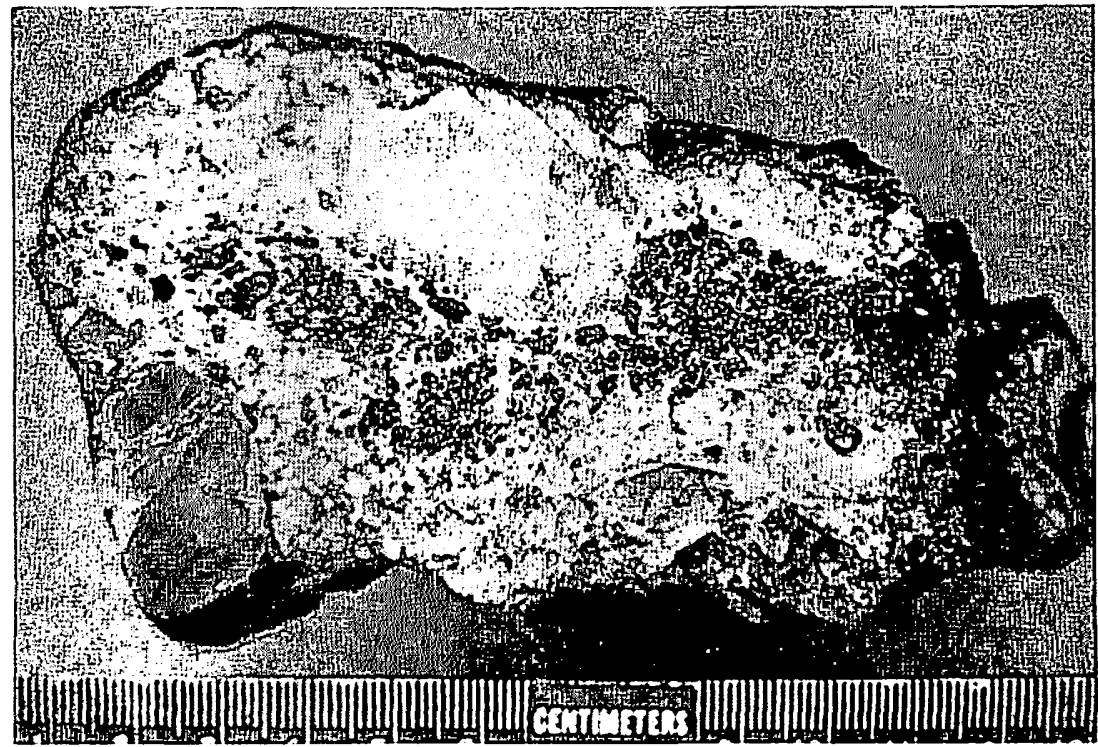

A. Cross section of a manganese nodule from the Mendocino Ridge ( $F a n 25 B D$ ), showing that the interior consists of palagonite tuff-breccia. Central part (darker shade) consists of fragments of fresh basaltic glass (sideromelane) in a matrix of reddish palagonite. Toward the surface fragments of basalt lie in a matrix of yellow altered palagonite.

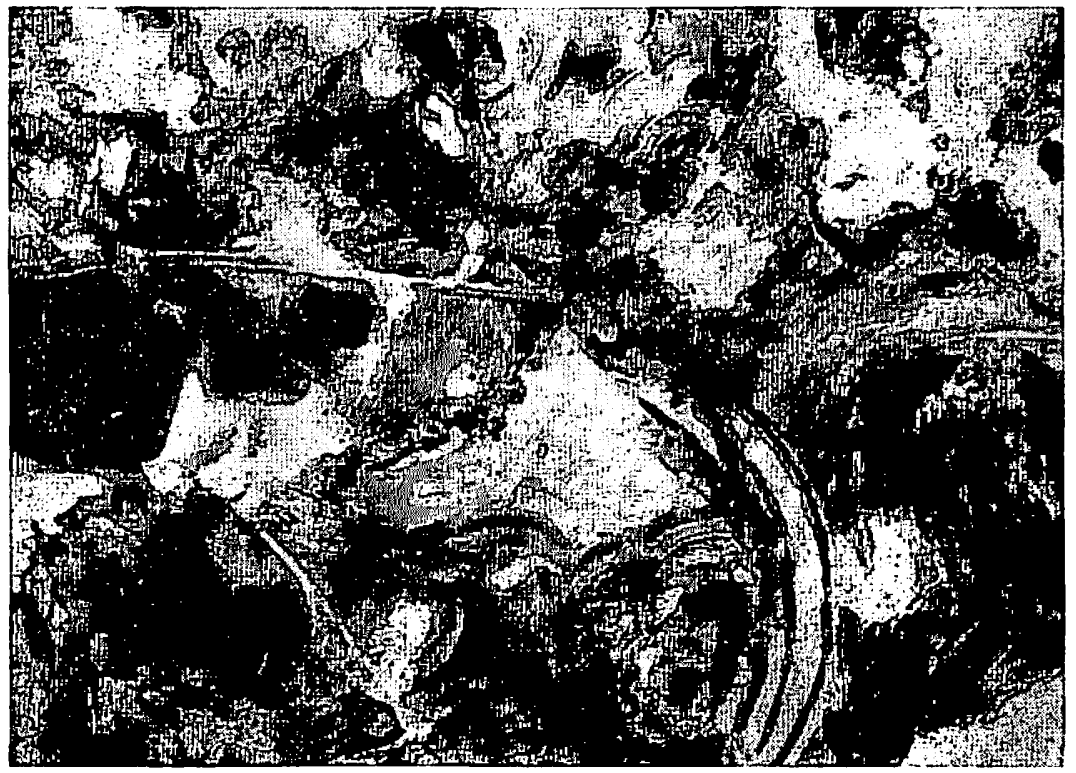

B. Thin section of the palagonite from the interior of sample $F a n 25 B D$. Segregations of iron and manganese oxides are seen within the palagonite, often with concentric and hair-like structures. 
the basaltic fragments consists of partially altered palagonite and is associated with abundant black ferromanganese oxides.

A thin section of the central, yellowish part of the specimen (see pl. 3-A) shows that the sideromelane fragments occupy nearly 30 percent of the section and that they are commonly free of microlite inclusions. The palagonite matrix is deep brownish yellow, and the margins where the sideromelane grades into palagonite are darkened with concentrations of ferruginous globulites. Within the palagonite itself are segregations of black and reddish-brown patches and semicircular rings, which are probably goethite and manganese oxides (pl. 3-B). Faintly birefringent phillipsite is also present. The presence of phyllosilicates of the smectite family is shown by $\mathrm{X}$-ray powder diffraction studies of this palagonitic matrix.

\section{Nodules from the South Pacific Ocean}

A. The first of two samples described here, $D W H D 72$, is one of several nodules dredged up in the South Pacific Ocean at $25^{\circ} 31^{\prime} \mathrm{S}$ and $85^{\circ} 14^{\prime} \mathrm{W}$, under $920 \mathrm{~m}$ of water. Its diameter is around $15 \mathrm{~cm}$, and its manganese and iron oxides form a crust about half a centimeter thick. A cross section shows that the interior consists of a brownish-yellow palagonite tuff (pl. 4.-A); dark oxides are also visible in the interior, in the form of veins and patches. Under the microscope this dark material looks exactly like that in the crust. It is concentrated along planes in the palagonite mass, giving the appearance of vein filling. The $\mathrm{X}$-ray diffraction analysis reveals the presence of goethite and of a smectite mineral, probably nontronite, within this specimen. Two broad reflections at $10 \AA$ and $7 \AA$ which disappear on treatment of the sample with a reducing agent (hydroxylamine sulfate) are probably the $10 \AA$ and $7 \AA$ manganites reported by Buser and Grütter (1956) as characteristic of the nodules.

B. The second sample, $D W H D 47$, comes from $41^{\circ} 51^{\prime} \mathrm{S}$ and $102^{\circ} 01^{\prime} \mathrm{W}$, under $4240 \mathrm{~m}$ of water. Its diameter is around $5 \mathrm{~cm}$; the dark crust is variable in thickness. The interior of this nodule consists of a yellow hyaloclastic material associated with black oxides identical to those of the crust and, in addition, abundant feldspar grains. An alkali feldspar is prevalent, probably of $\mathrm{K}$-analbitic composition, while an andesine plagioclase is present in lesser quantities.

\section{Hyaloclastites from the Oregon Coast}

Along the central Oregon coast submarine volcanism of the upper Eocene period produced typical pillow-palagonite complexes. Such formation is mentioned here only for comparison with previous deep sea samples. Vitreous particles of sideromelane can rarely be distinguished macroscopically in the palagonite matrix of this rock. Steel-gray and black layers and pockets of ferromanganese oxide minerals are clearly visible in some of the outcrops (pl. 4-B). In thin section the rock shows all the characteristics of palagonite tuff, also with zeolitic (phillipsite and natrolite) alterations. X-ray diffraction analysis of this material reveals in addition the presence of abundant nontronite. 
PLATE 4

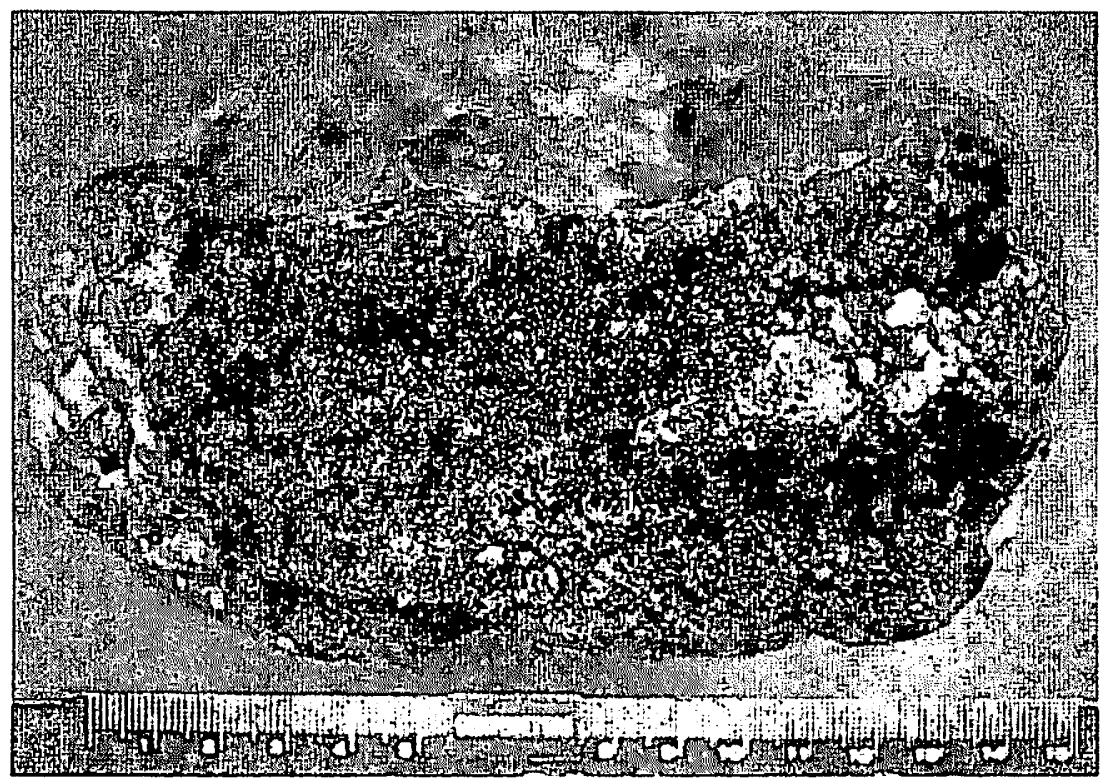

A. Broken manganese nodule from the South Pacific $(D W H D 72)$. The interior is a yellowish-brown hyaloclastite, containing veins and segregations of ferromanganese oxides similar to the crust.

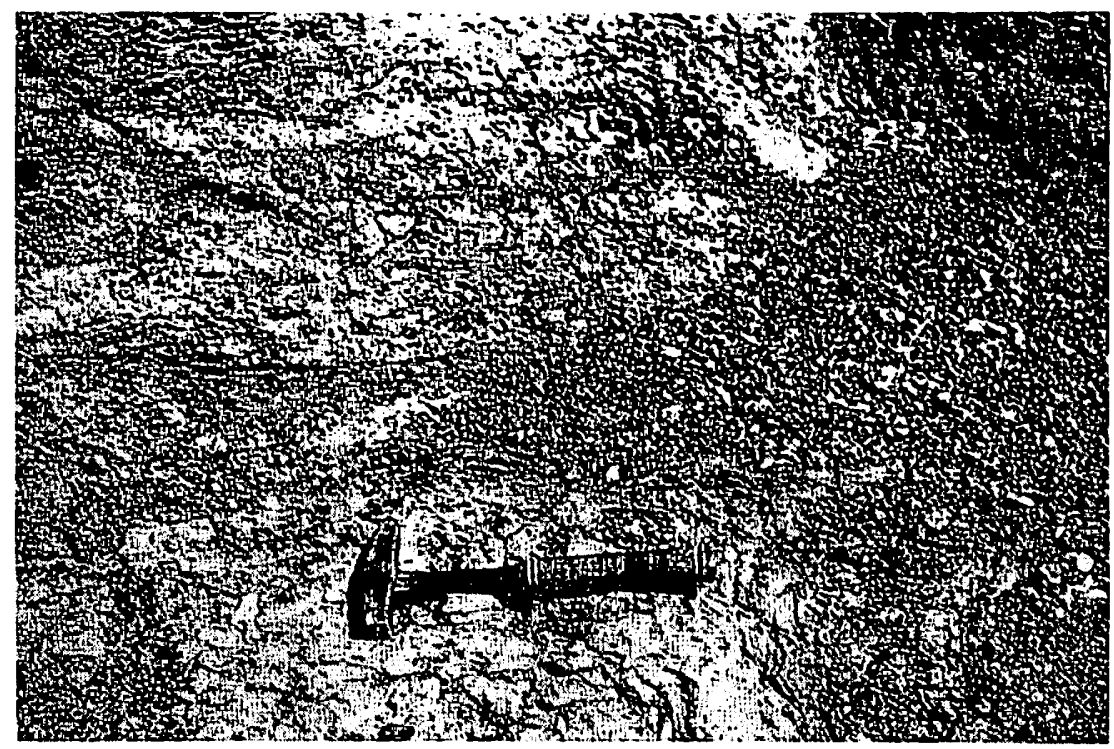

B. Outcrop of a palagonite tuff along the central Oregon coast. Color of the rock is yellowish-brown. Steel-gray ferromanganese oxides are concentrated in veins and patches, recognizable as dark bands in the picture. 


\section{Preliminary considerations}

As a premise to this discussion we will first mention briefly some of the phenomena occurring in connection with underwater lava extrusions. These phenomena are not yet fully understood. However, several studies, both on effusive rocks of various geologic ages known to have been originated by underwater eruptions as well as on samples directly dredged from the sea floor, allow a fairly clear picture of some of the processes involved, at least from a petrological point of view. A more detailed discussion as well as references on this subject can be found in Nayudu (1962a).

It appears that fluid basic lavas upon effusion on the sea floor often interact strongly with sea water. In certain cases rapid chilling processes take place which cause granulation or pulverization of the lava. The parts of the melt most directly reacting with sea water are hydrated and give rise to a material called palagonite, which is essentially a glass with a very high water content (up to 20 percent). The only crystalline components of relatively fresh palagonites are commonly nuclei of nontronite and occasionally of goethite. This palagonitic material often acts as a protective matrix around fragments of lava which do not react directly with water but cool to form normal basaltic glass (sideromelane) and/or eventually crystalline basalt. Such could well be the origin of the so called palagonite tuffs or using Rittmann's $(1962$, p. 72) terminology, hyaloclastites.

If great amounts of lava are extruded, a protective carapace of hyaloclastites usually seems to prevent the deeper fluid from rapid chilling and to allow its partial crystallization. On the other hand it is conceivable that at great depths in the ocean bottom where great masses of water are available at high pressure, many fluid basic lavas would for the most part, depending on their volume, react with water and cool to form palagonitic material.

The high hydration typical of palagonitic glasses causes their relatively rapid alteration in sea water; as a result, in addition to minerals of the montmorillonite family and to goethite, zeolites (commonly phillipsite) become the most abundant crystalline phase of these deposits. Also according to Nayudu (1962b; 1964), unstable palagonite develops into zeolites. It is significant that large areas of the Pacific Ocean floor, such as the South Pacific zeolite region, are made mostly of these components. Recently Bonatti (1963) showed that the phillipsite of the Pacific pelagic sediments is invariably accompanied by hyaloclastic material and by nontronite, and that incipient growth of the zeolite crystals takes place in the palagonite grains. There seems to be no evidence that the high concentrations of phillipsite of some pelagic sediments of the Pacific are formed in any way other than the one mentioned above. We can assume therefore that in general the presence of great quantities of these minerals on the ocean floor is directly related to underwater volcanic eruptions.

On the premise, we will briefly discuss the observations presented above, as well as results of several other authors, trying to test the Goldberg-Arrhenius hypothesis on the formation of the manganese nodules against the one advocating their local volcanic origin. 


\section{Two qualitative observations}

A. According to the Goldberg-Arrhenius hypothesis, the extraction of manganese and related metals from sea water would take place mainly on those surfaces of the specimen in direct contact with the freely circulating bottom water. Many nodules, with a more or less spherical shape, have their whole surface completely covered by a thick crust of ferromanganese oxides, even if only the upper part of their surface was in full contact with the bottom water while lying on the ocean floor. To avoid this difficulty Mero (1962) suggested that the nodules are frequently overturned by bottom feeding organisms. As every part of their surface would thus be periodically exposed to the water, this would explain their symmetric growth. However this explanation cannot be valid for a great number of nodules too large and heavy to be overturned by bottom fauna. The Horizon nodule (pl. 1) or the specimen (DWHD 72) shown in pl. 4-A can be mentioned as example. This latter nodule is nearly spherical with a diameter of around $20 \mathrm{~cm}$ and completely covered by an oxide crust about half a centimeter thick. It seems that these specimens, not uncommon, could have been formed by slow deposition of manganese from sea water only if they were floating somewhere above the ocean floor.

B. It has been observed that the nodule concentrations on the ocean floor vary widely from place to place. As an example reference may be made to two photographs from the bottom of the Atlantic, taken in a flat area a few dozen meters apart by B. Heezen (see Arrhenius, 1963). One shows a great number of nodules, whereas the other is almost free of them. Similar observations have been very common. Even taking into account the influence that deep sea currents might have on the process, it seems improbable that a slow deposition of manganese from a quite homogeneous solution such as sea water would give as a general result the high local variability in the concentration of the nodules, observed also in flat areas of the deep ocean floor.

These two qualitative observations already indicate the difficulties that the Goldberg-Arrhenius hypothesis encounters in explaining some very general features of the deep sea ferromanganese minerals.

\section{Association of the Nodules with Volcanics}

As already mentioned, manganese nodules are commonly found in close association with volcanic materials (Murray and Renard, 1891; Petterson, 1945; Mero, 1962; and others). Goldberg and Arrhenius (1958) and Arrhenius (1963) explain this fact as indicating merely a low rate of deposition of detrital matter in these areas, where as a result components such as authigenic minerals and residual volcanics would concentrate, which otherwise would be dispersed in the more abundant detrital sediment. These authors therefore assume that in general the association of ferromanganese oxides with volcanics does not require that a common origin of these two components be postulated. Some comments can be made on this point.

A. The assumption that manganese oxides are concentrated in sediments with very low rate of deposition does not seem to hold generally. In fact, nodules have also been found in several instances in localities with relatively high rates of sedimentation, such as the Gulf of California. 
Hutchinson (1947) demonstrated that no correlation exists between periods of lower sedimentation rate and higher manganese content in several cores from the Atlantic Ocean. Chemical analysis of samples collected by the Swedish Deep Sea Expedition showed that in some cores both from the Atlantic and the Pacific the vertical distribution of manganese.indicates very sharp maxima and minima (Landergren, 1954; Berrit and Rotshi, 1956). These fluctuations are so sharp that they cannot be explained only by variations in sedimentation rates during slow continuous chemical precipitation of manganese, as remarked also by Petterson (1959).

B. In regard to the petrographic associations between various phases within the nodules, the following can be noted: In the case of the Horizon nodule, the sediments normally deposited in the area of the ocean floor where this specimen was collected are predominantly terrigenous, consisting mainly of quartz, feldspars, muscovite, chlorite, et cetera. Some of this material was also found in a fissure of the specimen, as described on page 20 . The presence in this depositional environment of a pure zeolitite, such as the one found in the interior of the nodule, cannot be explained by a lower rate of sedimentation. Instead it suggests that some event interrupted the normal slow sedimentary accumulation in that part of the ocean bottom. The phillipsite and palagonite of the Horizon nodule are typical end products of the alteration of an under. water extruded lava. The structural patterns described above (pl. 2-A) in which the phillipsitic material is scattered in the manganese and iron oxide phases does not seem to accord with the very slow manganese deposition from sea water postulated by the Goldberg-Arrhenius hypothesis. On the contrary, their association is such as to suggest strongly a related genesis for these two components of the Horizon nodule, whose formation is thus likely to be related to a submarine eruption.

In the sample from the Mendocino Ridge (pl. 3-A) the thin sections show that abundant segregation of ferromanganese oxides, similar to that of the crust, are found within the palagonite (pl. 3-B). In the nodules from the south Pacific (DWHD 72), ferromanganese oxides are found not only in the thick outer crust but also in the interior of the core as veins, specks, and aggregates dispersed in the palagonitic material (pl. 4-A). Triassic manganese nodules found in fossil red clays from the island of Timor in the Malay Archipelago are also associated with volcanic material (Molengraff, 1920). Recently Arrhenius (1963) has shown that nontronite is intergrown with the manganese oxide phases in the Timor nodules. In none of the previous samples does the oxide crust appear to have been deposited on a preexisting nucleus of altered volcanics; many similar cases could be reported, beginning with some of those mentioned by Murray and Renard (1891).

It is, on the other hand, common to find segregations of ferromanganese oxides within hyaloclastic formations. One example was given previously describing the Eocene hyaloclastites from Oregon (pl. 4-B); another is provided by hyaloclastic rocks associated with a seamount from the southeast Pacific (lat $18^{\circ} 35^{\prime} \mathrm{S}$, long $126^{\circ} 25^{\prime} \mathrm{W}$ ), as shown in plate 2-B.

Observation of a great number of specimens from the Pacific Ocean floor shows the existence of a continuous range in the proportions between the two 
associated phases (ferromanganese oxides and hyaloclastites). Thus we pass from specimens of hyaloclastites with only minute ferromanganese segregations to samples predominantly of ferromanganese minerals with only very minor hyaloclastic remains.

C. Having noted in the foregoing paragraphs how in the nodules the oxide phases are often clearly associated with altered volcanic material, we shall now briefly consider the geographical distribution of the nodules in the Pacific Ocean, starting with a significant quotation from Goldberg (1961): "The authigenic zeolite of the deep sea floor, a phillipsite mineral, accompanies and possesses similar abundances to the ferromanganese minerals".

The manganese minerals are known to occur in particularly great abundance in a large area of the South Pacific. The only other major components of the ocean floor in this area are phillipsite crystals, often in concentrations of over 50 percent, clay minerals of the smectite group, and grains of palagonitic material, whereas terrigenous components are very scarce (Arrhenius and Bonatti, in preparation). The phillipsite crystals have been shown in this region to derive directly from the palagonite (Bonatti, 1963). Therefore there is evidence that the surface of the ocean floor in this region of abundant manganese nodules is made mainly of altered submarine lavas.

Another environment of the ocean floor where ferromanganese minerals are especially concentrated is the proximity and top of seamounts. These structures are commonly associated also with extensive palagonitic rocks, and sea floor deposits around them are frequently rich in zeolites and smectites. The volcanic origin of seamounts is generally recognized (Hamilton, 1956), and a possible mechanism for their formation is suggested by Nayudu (1962a). In general they can be regarded as the most conspicuous document of large scale submarine eruptions. In his monograph on the mid-Pacific mountain range, Hamilton (1956) reports that all the seamounts of that system have large deposits of manganese dioxide associated with mafic volcanic rocks. The same is reported for seamounts of the Gulf of Alaska (Menard and Dietz, 1951; Nayudu, 1962b) ; off southern California (Emery and Shepard, 1945) where the manganese minerals are associated with various rock types; of the Northeast Pacific (Carsola and Dietz, 1952) where they are associated with basaltic and palagonitic rocks. Matthews (1961) described samples of basalts and palagonitic tuffs associated with manganese oxides from an abyssal hill in the Northeastern Atlantic and expressed the opinion that the manganese was derived locally from the basalt.

It has been suggested that the extensive deposits of manganese minerals found on seamounts are there only because their tops are often places of little or no detrital deposition. Yet in many cases the same kind of manganese deposits found on the top of mounts can also be found in flat areas in their vicinity. A typical example is the Cobb seamount in the Gulf of Alaska and the nearby Cascadia plain, area of relatively high sedimentation rate; they are both rich in manganese oxides. It is also well known that the thickness of the manganese crust on rocks from the top of the same seamount or from the top of nearby and geologically related seamounts can be quite variable (Dietz, 1955), which seems an unlikely result if continuous slow precipitation were 
responsible for such deposits. These findings seem also in the case of seamounts to exclude low sedimentation rate as an important factor in the formation of their manganese deposits.

The observations reported in the previous paragraphs seem thus to give some evidence that both presence of volcanogenous phases within the nodules and the geographic association of the nodules with such phases in the Pacific cannot be considered a result of low rates of terrigenous sedimentation but on the contrary are such as to suggest a common origin for the volcanics and the ferromanganese minerals.

\section{Volcanic origin of the nodules}

If it is assumed that the ferromanganese minerals of the Pacific Ocean floor are genetically related to underwater volcanic eruptions, the following points can be raised:

A. How can manganese and iron be extracted from a submarine lava, and how can the manganese/iron ratio in the nodules be so much higher than in any normal basaltic magma?

B. How can the concentration in the nodules of minor elements such as $\mathrm{Cu}, \mathrm{Ni}, \mathrm{Zn}, \mathrm{Co}, \mathrm{Pb}$, et cetera, be explained?

C. What is the rate of accretion of the nodules?

D. What quantities of basaltic lavas would be needed to account for the observed concentrations of the ferromanganese minerals in the Pacific, and where are the remnants of these lavas?

We shall here consider these points separately.

A. Segregation of manganese during a submarine eruption.-It is well known that several manganese deposits (some even of economic importance) from different regions of the earth have been shown by various authors to be closely associated with underwater erupted mafic lavas. A classic example is that of the Olympic Peninsula (state of Washington) where Park (1946) showed that the manganese minerals are closely associated with spilitic pillow lavas. He found evidence that manganese was leached out of the magma at the time of the submarine eruption and deposited in pockets and slabs near the tops of the flows. An analagous situation is provided by manganese and copper deposits of early Cretaceous age from the Coquimbo province, Chile, described by Aquirre and Mehech (1964).

Among other examples are manganese deposits in Cuba (Park, 1942), in the Franciscan formation of California (Taliaferro and Hudson, 1943), in South America (Wurm, 1953), and in Japan (Yoshimura, 1953). These occurrences can hardly be a coincidence and suggest rather that the interaction of hot lavas with sea water provides a system favorable to the extraction of manganese from the lava itself. A convincing mechanism by which such an extraction and segregation of manganese could be provided is discussed at length by Krauskopf $(1956,1957)$. His hypothesis provides the basis for the following suggested mode of formation of deep sea ferromanganese deposits:

It is well known that the solution of iron and manganese compounds is favored by acid and reducing conditions. When basic lavas extruding on the ocean floor interact with large masses of sea water, this latter would provide a 
good solvent for the acid gases present in the magma. The resulting acid solutions circulating through the lava would leach out some iron, manganese, and other elements. This process would be favored by the extensive shattering and pulverization of the lava which often accompanies the effusion. More sea water would continually enter the system, neutralizing the acid and carrying oxygen, with the effect of precipitating first most of the iron, while manganese, more soluble, would become more and more concentrated and free of iron. By the time solutions enriched in manganese would come in contact with still more oxygen-bearing sea water, then manganese and some residual iron would be deposited to form nodules, slabs, and crusts, often together with fine hyaloclastic debris. The bulk of the manganese would thus be deposited in the areas surrounding the volcanic episode, while some might be transported to a distance.

The preceding paragraph admittedly oversimplifies the matter; nevertheless it very well explains petrological and chemical relationships of the above mentioned manganese deposits on land, and it is well supported by some laboratory experiments (see Krauskopf, 1957, p. 73). Lastly, it does not seem to contradict any of the basic features of the deep sea ferromanganese deposits.

Some evidence of the great mobility of iron and other metal ions when hot lavas and sea water interact can be seen by examining samples of palagonites. In thin section they often present characteristic segregations of dark oxides in the form of globulites, patches, and botryoidal structures such as those shown in plate 2-B or in plate 3-B. Observations of this kind have been made by several authors, starting with Peacock (1926) in his classic paper on the Icelandic palagonites. These structures confirm on a microscale that processes of migration and segregation of the metallic elements take place during high temperature interaction of lava and water.

It is interesting to note that Buser (1959) reported that the three Mn oxide minerals commonly found in the nodules represent increasing degrees of oxidation at their formation, in the order " $10 \AA$ manganite" $\rightarrow$ " $7 \AA$ manganite" $\rightarrow$ " $\mathrm{MnO}_{2}$ ". This result seems to agree with the above described mechanism of manganese deposition, which implies a progressively more oxidizing environment during precipitation.

Small scale segregation of iron and manganese due to the locally very variable "redox" and acidity conditions during an eruption could explain the formation of such "layering" as is observed in some nodules. Components of the bottom sediments may also become mixed with volcanic material during an effusion or suspended in the volcanogenous solutions; as a result, detrital minerals or biogenic remains may easily be trapped in the ferromanganese ag. gregates. Such is probably the origin of findings of shark's teeth or whale ear bones in manganese nodules from the Pacific.

The segregation of part of the manganese from the lava as described above may account for the high $\mathrm{Mn} / \mathrm{Fe}$ ratio observed in the nodules and in some associated sediments when compared with the same ratio in a basaltic magma, which is several times lower. The iron missing from the balance is presumably that precipitated in the earlier phases of the alkalinization and oxidation of the $\mathrm{Fe}$ and Mn rich solutions. Manganese nodules are quite often associated with 
ferruginous surface sediments; however, it is likely that some of the iron is preferentially buried beneath the surface of the ocean floor. It is difficult at present to make any quantitative balance on this item, because only a few chemical analyses have been done of sediments associated with the nodules, also because drillings from the top of sea mountains or long cores from the South Pacific zeolitite region are not yet available.

A secondary enrichment of manganese on the surface layers of oceanic sediments is probably also contributing to a high $\mathrm{Mn} / \mathrm{Fe}$ ratio measured in some pelagic clays. This enrichment is due to a slow upward migration of manganese from strata that upon burial and diagenesis enter a slightly reducing environment. Such a process, suggested already by Murray and Irvine (1895), was further discussed by Petterson (1945), who however could not find direct evidence of it in Correns' analyses of some short cores from the Atlantic. Goldschmidt (1954) also recognized its importance.

Recent data suggest that in certain deep sea sedimentary environments this migration of manganese actually takes place. An instance given in figure 1 shows the concentrations of reducible $\mathrm{Mn}$ in a North Pacific sedimentary core. The iron content of this core does not show any increase at the surface, not being affected by this process. Interesting observations on this subject were made by D. Lynn (ms), who while studying sediments from the east tropical Pacific found a dark, manganese rich layer at the top strata of several cores. The thickness of this layer augments in cores increasingly distant from the Central American continent (fig. 2), and the sediment below this layer gives evidence of reducing conditions.

Bezrukov (1960) in his study of the western Pacific sediments likewise found at the surface of the sediments a layer with a higher manganese content than the strata below. In different areas this oxidized layer is of variable thickness, which seems to increase toward the open ocean where the length of the usual piston cores is insufficient to go through it. His Eh measurements appear to confirm the solution and upward migration of manganese from buried reduced sediments.

The dissolution of $\mathrm{Mn}$ oxides when buried in reduced sediments could perhaps at least partially account for the qualitative observation that $\mathrm{Mn}$

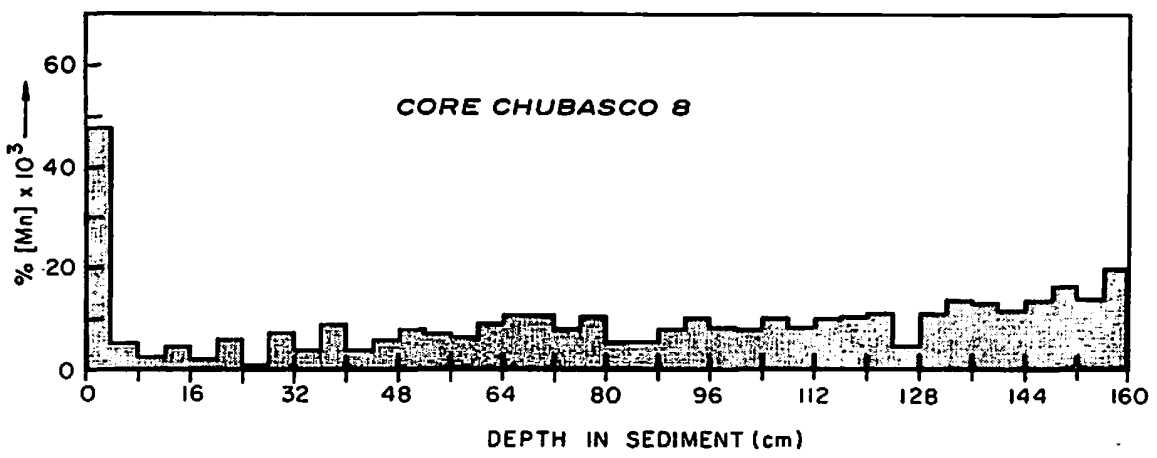

Fig. 1. Concentrations of reducible manganese (extracted by hydroxylamine sulfate) in a core from the North Pacific (Chubasco 8, lat $10^{\circ} 13.5^{\prime} \mathrm{N}$, long $125^{\circ} 25.3^{\prime} \mathrm{W}$ ). 


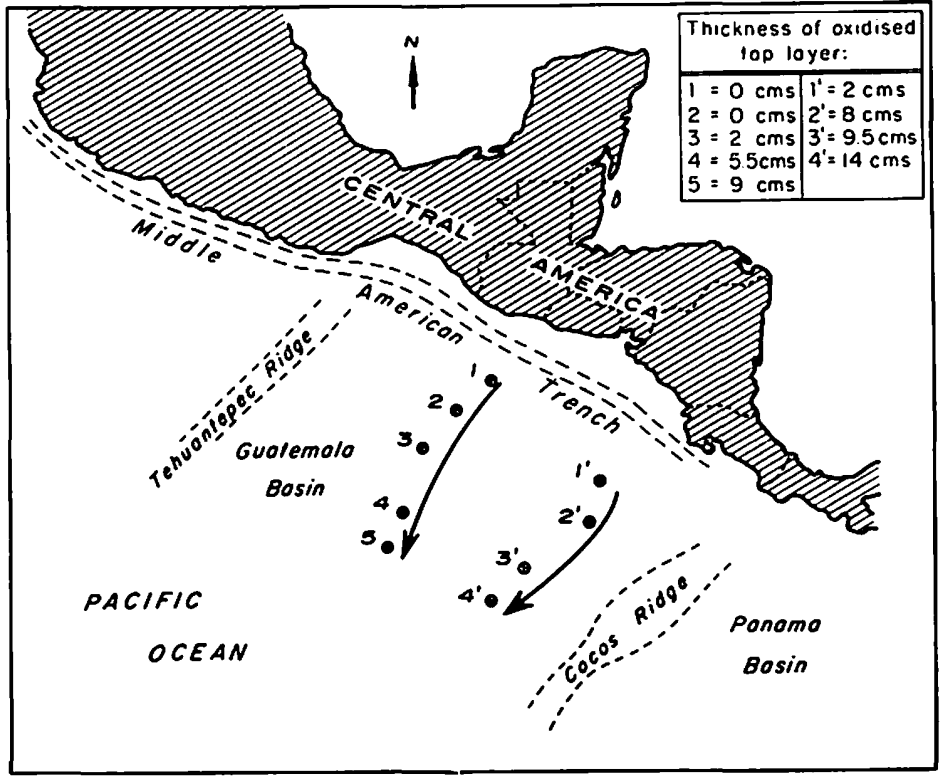

Fig. 2. Location of some sediment cores in the Guatemala Basin showing thickening of manganese-rich top layer away from the continental margin (after Lynn, ms).

nodules are preferentially found at the surface of the sediments, rather than buried in them.

B. Minor elements in the nodules.-To explain the striking concentration in the nodules and in some associated sediments of rare elements such as $\mathrm{Ni}$, $\mathrm{Co}, \mathrm{Cu}, \mathrm{Pb}, \mathrm{Zn}$, and some rare earths, Goldberg (1954) suggested that these elements are scavenged through absorption from sea water by the iron and manganese oxides. He pointed out that this hypothesis would be verified if one could observe that the ratio scavenger element/scavenged element is roughly constant in pelagic clays and manganese nodules. The following considerations can be made on this matter:

1. In the typical case of manganese (scavenger) versus nickel (scavenged), Goldberg (1954) reported that the $\mathrm{Mn} / \mathrm{Ni}$ ratios in pelagic cores collected by the Swedish Deep Sea Expedition and analyzed by Rotshi (1952) are nearly constant, thus supporting the scavenging hypothesis. Nevertheless Petterson (1959) pointed out that, although Goldberg had used in his calculations the average value of $\mathrm{Mn}$ and $\mathrm{Ni}$ for each core, consideration of the single values for $\mathrm{Mn}$ and $\mathrm{Ni}$ in each core would reveal a great variability in their ratio.

2. Figure 3 (from Revelle and others, 1955) shows a plot of $\mathrm{Mn}$ and $\mathrm{Ni}$ values in a core from the North Pacific (Capricorn $50 \mathrm{BP}$ ). This core consists of two sections of different composition: the top section is made predominantly of terrigenous minerals, evidently deposited by slow sedimentation processes, whereas the lower one is rich in zeolites, smectites, and ferromanganese oxides. The $\mathrm{Mn} / \mathrm{Ni}$ ratios are different in the two sections, suggesting that the mechanism of slow deposition of the two elements operating in the upper section is 


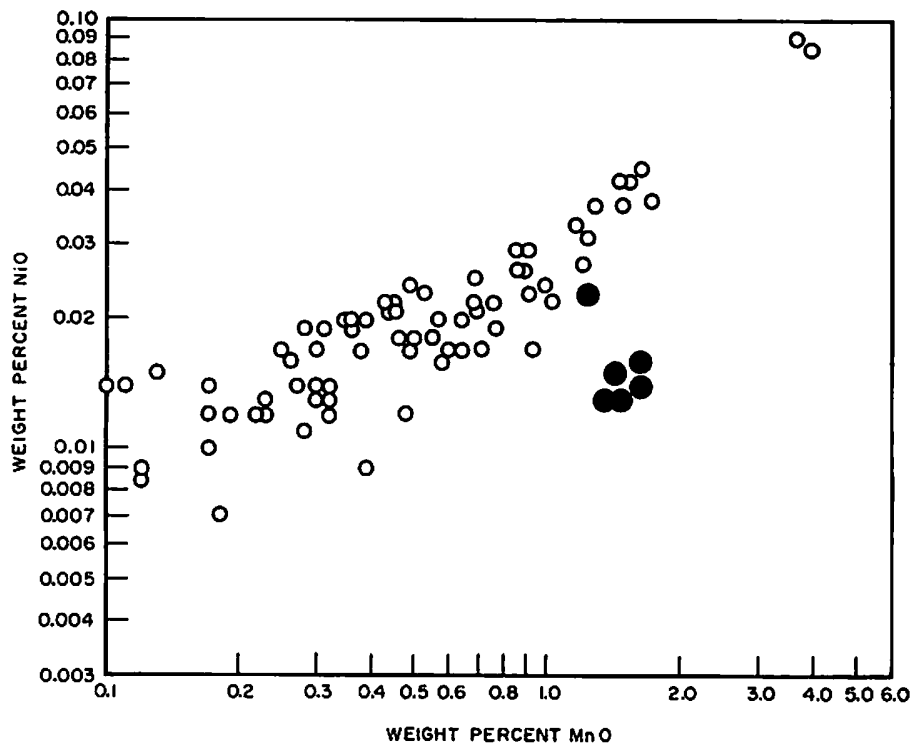

Fig. 3. Relation between manganese and nickel content in core Capricorn $50 \mathrm{BP}$, lat $14^{\circ} 55^{\prime} \mathrm{N}$, long $124^{\circ} 12^{\prime} \mathrm{W}$ (from Revelle and others, 1955).

shadowed in the lower by the presence of a close by, new source of manganese and possibly of nickel. The petrological composition of the lower section of the core (mainly alteration products of hyaloclastites) is suggestive as to the nature of such a source.

3. Another core from the North Pacific (Chinook 2) shows similar features: it is $58 \mathrm{cms}$ long and is made of a lower, dark section, consisting mainly of ferromanganese oxides, nontronite, and palagonitic glass, which grades up into a layer 3 or $4 \mathrm{cms}$ thick of almost pure phillipsite. Above such a layer a discontinuity exists, and the upper $25 \mathrm{cms}$ long section of the core is made of terrigenous minerals such as quartz, feldspars, micas, and chlorites, that is, the normal components of the sediments in that area of the ocean. Chemical analyses of this core (Chow, 1958) show that elements such as $\mathrm{Fe}, \mathrm{Mn}, \mathrm{Ni}, \mathrm{Co}$, $\mathrm{Pb}$, and $\mathrm{Cu}$ are enriched several times in the lower section relative to the upper one. The $\mathrm{Ni} / \mathrm{Co}$ ratio is nearly constant in samples from the upper section (deposited by normal, slow sedimentation), but it varies widely in those from the lower section (fig. 4). The presence of a local volcanic source is suggested in the latter case. It is significant that the scavenging hypothesis appears questionable in those cases where relatively high concentrations of ferromanganese oxides are present.

4. The $\mathrm{Ni} / \mathrm{Co}$ ratio in ocean water is about 7 (Goldberg, 1961), whereas in the manganese nodules this ratio, though variable, is on the average near to 1. This enrichment of cobalt in the nodules by slow depositional processes is not easy to explain especially since the oxidation of $\mathrm{Co}^{+2}$ to $\mathrm{Co}^{+3}$ is thermodynamically unlikely to proceed at concentrations typical of sea water (Goldberg, 1961). Davidson (1962), in reviewing published data on $\mathrm{Co}$ and $\mathrm{Ni}$ in various rock types and ore deposits, pointed out that $\mathrm{Ni}$ is always more abun- 


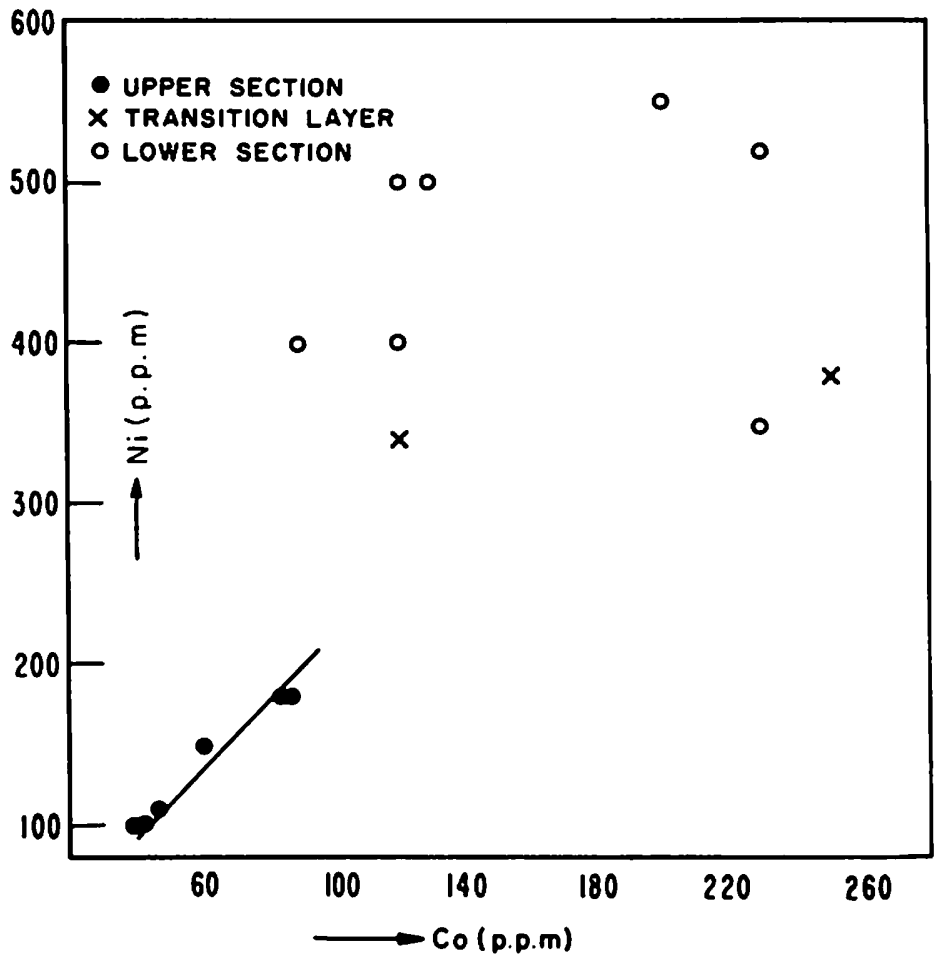

Fig. 4. Relation between nickel and cobalt in core Chinook 2, lat $35^{\circ} 09^{\prime} \mathrm{N}$, long $157^{\circ} 17.5^{\prime}$ W (chemical analyses by Chow, 1958).

dant than $\mathrm{Co}$ in sediments of all kinds, whereas the $\mathrm{Ni} / \mathrm{Co}$ ratio reaches or goes below 1 only in certain igneous rocks and in ore deposits of direct igneous origin.

5. It has been observed that the chemical composition of the nodules differs considerably from place to place, namely that the ratios $\mathrm{Mn}: \mathrm{Fe}:$ Rarer metals differ among nodules dredged from different localities of the ocean bottom. For instance, Goldberg (1961) reports nodules made almost exclusively of Mn oxides with practically no iron, cobalt, nickel, copper, et cetera, whereas in other instances nodules can contain as much as 20 percent iron. If the Goldberg-Arrhenius hypothesis is accepted, it is rather hard to explain why in nodules formed far away from the source of their components (the continents), such drastic variations of chemical composition should occur.

According to Mero (1962) the floor of the Pacific Ocean can be divided very roughly into regions, each growing nodules of similar composition (fig. 5). It has been suggested (Arrhenius, 1963) that marine planktonic organisms are responsible for the extraction from sea water of some of the rare metals, thus on their death concentrating the element in the bottom environment of certain deep sea regions. This process might certainly be important in particular problems of marine geochemistry. As for the manganese nodules however, it does not seem that the regional trends shown in figure 5 can be made to fit any major biogeographic trend of the Pacific. 


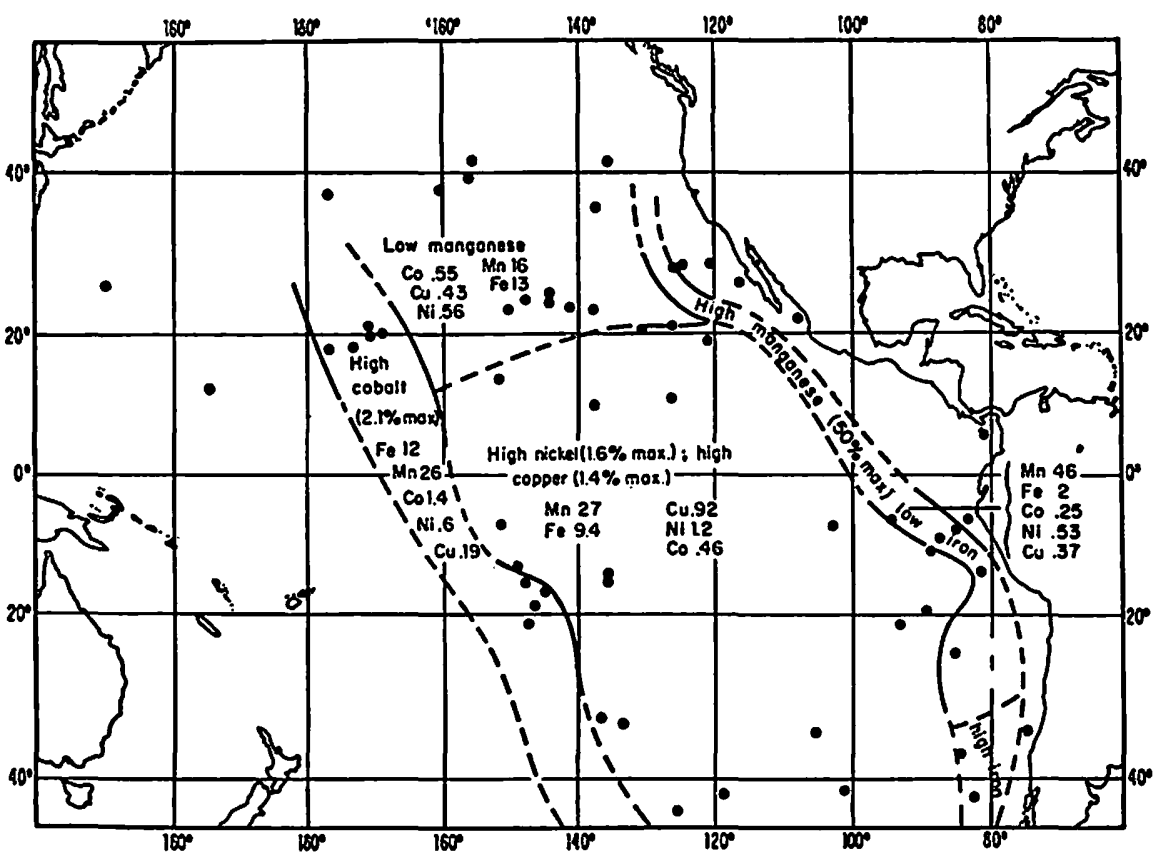

Fig. 5. Regional variation in chemical composition of manganese nodules. The average composition and the maximum concentration of characteristic elements are shown for each area (after Arrhenius, 1963).

Many factors are involved in the process of formation of manganese nodules suggested earlier in this paper. In general very unstable redox and acidity conditions will operate during a submarine eruption, causing for instance the segregation of manganese from iron to be achieved to a greater or lesser degree, according to purely local conditions. As a result nodules with a wide range in the ratios of their chemical components can probably be originated by one and the same volcanic source. Yet in general, nodules deriving from the same magmatic source should tend statistically to have a similar chemical composition. On this basis it could perhaps be possible to explain some of the trends of figure 5 . We find for instance a well defined region whose nodules are relatively rich in manganese and poor in iron. This region follows very closely the profile of the East Pacific Rise, which is partly associated with an intermediate type of volcanism, contrasting with the more basic kind in most of the Pacific basin (Peterson and Goldberg, 1962). Andesitic magmas are known to have on the average a much higher $\mathrm{Mn} / \mathrm{Fe}$ ratio than more basic magmas (Goldschmidt, 1954). Therefore the relatively greater amount of manganese available in these lavas would be reflected in the composition of the nodules. Likewise the high cobalt content of the nodules in the Hawaiian region might be related to that type of volcanism, as also indicated by Mero (1962). These nodules are also relatively rich in iron, and it is a known fact that Co follows $\mathrm{Fe}$ closely in its igneous chemistry. Admittedly interpretations of the compositional map of figure 5 are still almost barely speculative. Yet the 
regional trends of that map seem at present to favor a volcanic origin for the nodules, rather than to oppose it.

It thus appears from this discussion that the minor elements $(\mathrm{Ni}, \mathrm{Co}, \mathrm{Cu}$, $\mathrm{Pb}$, et cetera) concentrated in the nodules may be at least in part volcanically derived, according to processes of the kind suggested in an earlier section. A volcanic origin for those elements in the nodules has also been independently suggested by Hewett, Fleischer, and Conklin (1963).

C. Rate of accretion of the nodules.-Ferromanganese oxides lying on the ocean bottom are likely to adsorb chemical species from the water (Goldberg, 1954). If the volcanic origin of the nodules is admitted, then most likely they were formed in a relatively short time; the elements adsorbed from sea water after their formation would have to be mainly concentrated in their surface layers. Hence it is worthwhile to note that several nodules contain ionium and its daughter elements concentrated in their surface layers. Some authors (Petterson, 1943; Von Buttlar and Houtermans, 1950) have used radium data to calculate rates of accretion of the nodules, on the assumption that unsupported $\mathrm{Ra}$ is constantly deposited on the nodules and that these are formed by slow deposition from sea water. In the foregoing pages we have tried to show that this last assumption does not seem to be valid; in such case, the rates calculated from the radium measurements would be meaningless. The same would apply to some data of Goldberg and Picciotto (1955) and Goldberg (1961), who found the ratio ionium/thorium much higher on the surface of the Horizon nodule than directly under its surface and on such basis calculated its rate of accretion.

It is noteworthy that rates of accretion calculated for the nodules by the above methods can be shown independently to be quite improbable. Goldberg (1961) gave for the Horizon nodule an average rate of accretion of less than $0.01 \mathrm{~m}$ per thousand years. Since the sediments associated with this specimen are deposited at a rate certainly higher than $1 \mathrm{~mm}$ per thousand years, it follows that this nodule would have soon been buried, without being able to grow at all. The same would be valid for most Pacific ferromanganese minerals. In fact the presence on the southwest Pacific floor of abundant nodules with supposedly lower rates of accretion than the associated sediments was desig. nated as puzzling by Menard and Shipek (1958). To solve this apparent puzzle Menard (1964, p. 183) invoked as deus ex machina the action of bottom fauna, which would continuously push up the nodules and keep them at the surface of the sediment. However, considering the size of some of the nodules, such an hypothesis seems to overestimate the physical capacity of bottom organisms.

If somewhat higher rates of accretion are assumed (for instance, rates from the data of Petterson, 1943, or from those of Von Buttlar and Houtermans, 1950), then other difficulties are encountered. For instance Dietz (1955) observed that rocks on the top of some mid-Pacific seamounts where no sediments have been deposited since the Cretaceous have a crust of manganese oxides only a few centimeters thick at the most. With rates of the order of $1 \mathrm{~mm}$ per thousand years a manganese crust $100 \mathrm{~m}$ thick would have to cover those seamounts. 
D. Extent of submarine volcanism needed to account for the nodules in the Pacific.-Paucity of quantitative data precludes at present a reliable estimate of how much lava would account for the amount of manganese nodules observed in different areas of the ocean floor. However, a rough guess would indicate that a basaltic flow $1 \mathrm{~m}$ thick, density 2.9 , containing 0.1 percent of manganese, would release $290 \mathrm{gr}$ of manganese per square meter of ocean floor. This assumes that only 10 percent of the manganese is leached out from the lava and concentrated at the bottom. These figures show that relatively small mafic submarine eruptions could provide enough manganese to explain the $\mathrm{MnO}_{2}$ concentrations observed with deep sea cameras in areas in which nodules are plentiful (Mero, 1962; Skornyakova, 1960).

The Pacific basin is rich in evidence of very extensive submarine volcanism. Products of the alteration of palagonites cover large areas of the ocean floor (Bonatti, 1963). Seamounts and guyots are a common feature of subaqueous topography, and outcrops and slabs of volcanic materials are widely spread on the ocean bottom (Menard, 1960). Minerals of local volcanic origin are common in the sediments of certain areas of the ocean. Therefore submarine volcanism should not be underestimated when speculating on geochemical balances in the Pacific basin, particularly in regard to such elements as manganese, which is much more abundant in pelagic deposits (red clays) than in igneous or other sedimentary rocks (Kuenen, 1950).

\section{CONCLUSIONS}

The processes described in this paper imply the following:

A. Weathering of manganese from the continents, its dilution in the ocean, and its slow precipitation on the bottom is clearly an important process in marine chemistry, as pointed out by several authors; however, such a mechanism does not seem to be responsible for the formation of manganese nodules.

B. Submarine volcanism is a major source of manganese in the Pacific, to be noted as well as continental weathering; deep sea ferromanganese nodules appear to be mainly related to such a source.

C. Manganese will in general tend to be concentrated toward the top of the deep sea sedimentary column, and it may be wrong to extrapolate the data we have from near surface samples to deep buried strata.

If these suggestions are taken into account, some of the conclusions drawn by Goldberg and Arrhenius (1958) from their geochemical calculations in regard to manganese and related elements may need some revisions.

\section{ACKNOWLEDGMENTS}

We are very grateful to Dr. G. Arrhenius for his generous support of this work and for fruitful criticism of the manuscript, which also benefited from suggestions by Drs. K. Boström, M. N. Bramlette, and D. C. Lynn. Our thanks are also due to B. Starr and E. Nayudu for their assistance. This research was sponsored by the U. S. Atomic Energy Commission (A.T. (11.1) 34), the National Science Foundation (Grant G 21518), and the American Chemical Society's Petroleum Research Fund (PRF 875.06), and in part by the Office 
of Naval Research Contract Nonr-477(10) Project NR083-12. The support from these agencies is gratefully acknowledged.

\section{REFERENCES}

Aguirre, Luis, and Mehech, Sonia, 1964, Stratigraphy and mineralogy of the manganese sedimentary deposits of Coquimbo Province, Chile: Econ. Geology, v. 59, p. 428-442.

Arrhenius, Gustaf, 1963, Pelagic Sediments, in Goldberg, E., Hill, M., Iselin, C., and Munk, W., The sea, ideas and observations: New York, Interscience Publishers, p. 655-727.

Berrit, G. R., and Rotschi, H., 1956, Chemical analyses of cores from the central and west equatorial Pacific: Swedish Deep-Sea Exped., 1947-1948, Rept., v. 6, fascicle 2, p. 51 58.

Bezrukov, P. L., 1960, Sedimentation in the north-western part of the Pacific Ocean: Internat. Geol. Cong., 2lst, Copenhagen, 1960, Repts., pt. 10, p. 39.49.

Bonatti, E., 1963, Zeolites in the Pacific pelagic sediments: New York Acad. Sci. Trans., v. 25 , no. 8 , p. $938-948$.

Buser, W., 1959, The nature of the iron and manganese compounds in manganese nodules [abs.] : Internat. Oceanog. Cong., lst, New York 1959, Preprints (Am. Assoc. Adv. Sci.), p. 962.964 .

Buser, W., and Grütter, A., 1956, Uber die Natur der Manganknollen: Schweiz Mineralog. Petrog. Mitt., v. 36, p. 49.62 .

Buttlar, H. Von, and Houtermans, F. G., 1950, Photographische Bestemmung der Aktivitatverteilung in einer Manganknolle der Tiefsee: Naturwissenschaften, v. 37, p. 1-4.

Carsola, A. J., and Dietz, R. S., 1952, Submarine geology of two flat-topped northeast Pacific seamounts: Am. Jour. Sci., v. 250, p. 481-497.

Chow, T. J., 1958, Lead isotopes in sea water and marine sediments: Jour. Marine Research, v. 17, p. 120-127.

Clarke, F. W., 1924, The data of Geochemistry, 5th ed.: U. S. Geol. Survey Bull. 770, $841 \mathrm{p}$.

Correns, C. W., 1941, Beiträge zur Geochemie des Eisens und Mangans: Akad. Wiss., Göttingen, Math.Phys. Kl. Nac., v. 5, p. 219-230.

Davidson, C. F., 1962, On the cobalt:nickel ratio in ore deposits: Mining Mag., v. 106, p. 78.85.

Dietz, R. S., 1955, Manganese deposits on the northeast Pacific sea floor: Calif. Jour. Mines and Geology, v. 51, p. 209-220.

Dorff, F., 1935, Biologie des Eisens- und Mangankreislaufes: Berlin, Verlags Gesell. fur Áckerbau, $106 \mathrm{p}$.

Emery, K. O., and Shepard, F. P., 1945, Lithology of the sea floor off Southern California: Geol. Soc. America Bull., v. 56, p. 431-477.

Goldberg, E. D., 1954, Marine geochemistry, pt. 1. Chemical scavengers of the sea: Jour. Geology, v. 62 , p. $249-265$.

1961, Chemistry in the oceans, in Sears, M., Oceanography: Washington, D. C., Am. Assoc. Adv. Sci., pub. no. 67, p. 583-597.

Goldberg, E. D., and Arrhenius, Gustat, 1958, Chemistry of Pacific pelagic sediments: Geochim. et Cosmochim. Acta, v. 13, p. 153-212.

Goldberg, E. D., and Picciotto, E. E., 1955, Thorium determinations in manganese nodules: Science, v. 121, p. 613-614.

Goldschmidt, V. M., 1954, Geochemistry: Oxford, Clarendon Press, 730 p.

Graham, J. W., 1959, Metabolically induced precipitation of trace elements from sea water: Science, v. 129 , p. 1428-1429.

Hamilton, E. L., 1956, Sunken islands of the mid-Pacific mountains: Geol. Soc. America Mem. 64, 97 p.

Hewett, D. F., Fleischer, Michael, and Conklin, Nancy, 1963, Deposits of the manganese oxides: Supplement: Econ. Geology, v. 58, p. 1-49.

Hutchinson, G. E., 1947, The problems of oceanic geochemistry: Ecology Mon., v. 17, p. 299.315.

Krauskopf, K. B., 1956, Separation of manganese from iron in the formation of manganese deposits in volcanic association: Internat. Geol. Cong. 20th, Mexico 1956, Rept., p. 119-131.

p. 119-137, Separation of manganese from iron in sedimentary processes: Geochim. et Cosmochim. Acta, v. 12, p. 61.84.

Kuenen, P. H., 1950, Marine Geology: New York, John Wiley and Sons, 551 p.

Landergren, Sture, 1954, On the geochemistry of the north Atlantic sediment core no. 238: Swedish Deep-sea Exped., 1947-1948, Rept., v. 7, fascicle 2, p. $123-148$. 
Lynn, D. C., ms, 1964, Sediments from the Guatemala Basin: Ph.D. thesis, Univ. California, San Diego, California.

Mathews, D. H., 1961, Lavas from an abyssal hill on the floor of North Atlantic Ocean: Nature, v. 190 , no. 4771 , p. $158-159$.

Menard, H. W., 1960, Consolidated slab on the floor of the eastern Pacific: Deep-Sea Research, v. 7, p. 35.41.

$\longrightarrow$ 1964, Marine Geology of the Pacific: New York, McGraw-Hill Co., 271 p.

Menard, H. W., and Dietz, R. S., 1951, Submarine geology of the Gulf of Alaska: Geol. Soc. America Bull., v. 62, p. 1263-1285.

Menard, H. W., and Shipek, C. J., 1958, Surface concentrations of manganese nodules: Nature, v. 182 p. $1156-1158$.

Mero, J. L., 1962, Ocean-floor manganese nodules: Econ. Geology, v. 57, p. 747-767.

Molengraaff, G., 1920, On manganese nodules in Mesozoic deep-sea deposits of Dutch Timor: Royal Acad. Sci. Amsterdam, Proc., v. 23, no. 7, p. 997-1012.

Murray, $J .$, and Irvine, $R$., 1895, On the manganese oxide and manganese nodules in marine deposits: Roy. Soc. Edinburgh Trans., v. 37, p. 721-742.

Murray, J., and Renard, A. F., 1891, Deep.Sea deposits: Challenger Exped. Rept. [London], $525 \mathrm{p}$.

Nayudu, Y. R., 1962a, A new hypothesis for origin of guyots and seamount terraces, in MacDonald, G. A., and Kuno, Hisashi, eds., The Crust of the Pacific Basin: Geophys. Mon. no. 6, p. 171-180.

$1962 \mathrm{~b}$, Submarine eruption of basalts and the problems of palagonitization: Internat. Symposium on Volcanology, Japan, Abs., p. 49.

1964, Palagonite tuffs (hyaloclastites) and the products of post-eruptive processes: Internat. Assoc. Volcanology Symposium, (I.U.G.G.) XIII Gen. Assembly, Berkeley, California, 1963, Bull. Volcanol., v. 25, in press.

Park, C. F., 1942, Manganese deposits of Cuba: U. S. Geol. Survey Bull. 935B, p. 75-97.

1946, The spilite and manganese problems of the Olympic Peninsula, Wash. ington: Am. Jour. Sci., v. 244, p. 305-323.

Peacock, M. A., 1926, The petrology of Iceland (Tyrrel and Peacock) Pt. 1, The basic tuffs: Roy. Soc. Edinburgh Trans., v. 55, p. 51-76.

Peterson, M. N., and Goldberg, E. D., 1962, Feldspar distribution in South Pacific pelagic sediments: Jour. Geophys. Research, v. 67, p. 3477-3492.

Pettersson, H., 1943, Manganese nodules and the chronology of the ocean floor: Goteborg Oceanog. Inst. Medd., v. 2B, no. 5, p. 1-39.

1945, Iron and manganese on the ocean floor: Goteborg Oceanog. Inst. Medd., v. 3B, no. 7, p. 1.37 .

1959, Manganese and nickel on the ocean floor: Geochim. et Cosmochim. Acta, v. 17, p. 209-213.

Revelle, R. R. D., Bramlette, M. N., Arrhenius, Gustaf, and Goldberg, E. O., 1955, Pelagic sediments of the Pacific, in Poldervaart, Arie, ed., Crust of the Earth-a symposium: Geol. Soc. America Spec. Paper 62, p. 221-235.

Rittman, Alfred, 1962, Volcanoes and their activity: New York, John Wiley and Sons, 305 p.

Rotschi, H., 1952, Study of the iron, manganese and nickel contents of some deep-sea cores: Centre Recherche Oceanog. Cahiers. no. 4, p. 2-22.

Skornyakova, N. S., 1960, Manganese concretions in sediments of the northeastern Pacific Ocean: Akad. Nauk. USSR Doklady, v. 130, p. 653-656.

Taliaferro, N. L., and Hudson, F. S., 1943, Genesis of the manganese deposits of the coast ranges of California: Calif. Div. Mines Bull. 125, p. 217-275.

Wurm, Adolf, 1953, Uber Manganerzvorkommen in den Anden Sudamerikas: Neues Jahrb. Geologie u. Paläontologie Abh., v. 96, p. 173-179.

Yoshimura, Toyofumi, 1953, Types of manganese deposits of Japan: Pacific Sci. Cong., 7th, New Zealand, Proc., v. 2, p. 215-217. 


\section{UNCLASSIFTED TECHNICAL REPORTS DISTRIBUTION LIST \\ for OCEANOGRAPHIC CONTRACTORS \\ of the GEOPHYSICS ERANCH \\ of the OFFICE OF NAVAL RESEARCH \\ (Revised April 1965)}

\section{DEPARTMENT OF DEFENSE}

1 Director of Defense Research

\& Engineering

Attn: Coordinating Committee on Science

Pentagon

Washington, D.C.

I Attn: Office, Assistant Director (Research)

$\underline{\text { Navy }}$

2 Office of Naval Research

Geophysics Branch (Code 416)

Washington, D.C. 20360

Office of Naval Research

Washington, D.C. 20360

I Attn: Biology Branch (Code 446)

1 Attn: Surface Branch (Code 463)

1 Attn: Undersea Programs (Code 466)

1 Attn: Field Projects (Code 418)

1 Commanding officer

Office of Naval Research Branch 495 Summer street

Boston, Massachusetts 02110

I Commanding officer

Office of Naval Research Branch

207 West 24th Street

New York, New York 10011

1 Commanding Officer

Office of Naval Research Branch

230 North Michigan Avenue

Chicago, Illinois 60601

1 Commanding officer

Office of Naval Research Branch 1000 Geary Street

San Francisco, California 94109
1 Commanding Officer Office of Naval Research Branch 1030 East Green Street

Pasadena, California 91101

10 Commanding Officer Office of Naval Research Branch Navy \#100, Fleet Post Office New York, New York

1 Oceanographer

Office of Naval Research

Navy \#100, Box 39

Fleet Post Office

New York, New York

1 Contract Administrator

Southeastern Area

Office of Naval Research

2110 "G" street, N.W.

Washington, D.C. 20007

1 ONR Special Representative

c/o Hudson Laboratories

Columbia University

145 Palisade Street

Dobbs Ferry, New York 10522

1 Your Resident Representative

Office of Naval Research

6 Director

Naval Research Laboratory

Attn: Code 5500

Washington, D.C.

(Note: 3 copies are forwarded by the above addressee to the British Joint Services Staff for further distribution in England and Canada.)

1 Oceanographer

Office of the Chief of Naval Operations OP-O9B5

Washington, D.C. 
1 Commander

U.S. Naval Oceanographic Office Washington, D.C.

At.tn: Library (Code 1640)

1 U.S. Naval Branch Oceanographic Office Navy 3923, Box 77, FPO

San Francisco, California

Chief, Bureau of Naval Weapons Department of the Navy Washington, D.C.

1 Attn: FASS

1 Attn: RU-222

1 Offjre of the U.S. Naval Weather Service

U.S. Naval Station

Washington, D.C.

1 Chief, Bureau of Yards \& Docks Office of Research

Department of the Navy

Washington, D.C.

Attn: Code 70

1 Commanding Officer \& Director U.S. Navy Electronics Laboratory San Diego, California 92152

1 Attn: Code 3102

1 Attn: Code 3060C

1 Commanding Officer \& Director U.S. Naval Civil Engineering Laboratory

Port Hueneme, California

Attn: Code I54

Commanding Officer

Pacific Missile Range

Pt. Mugu, California

1 Attn: Code 3145

1 Attn: Code 3250

1 Commander, Naval Ordnance Laboratory White Oak, Silver Spring, Maryland

Attn: E. Liberman, Librarian
Commanding Officer

Naval Ordnance Test Station

China Lake, California

1 Attn: Code 753

1 Attn: Code 502

1 Commanding officer

Naval Radiological Defense Laboratory

San Francisco, California

1 Commanding Officer

U.S. Naval Underwater Ordnance Station

Newport, Rhode Island

Chief, Bureau of Ships

Department of the Navy

Washington, D.C.

1 Attn: Code 1622B

1 Officer-in-Charge

U.S. Navy Weather Research Facility

Naval Air Station, Bldg. R-48

Norfolk, Virginia

1 U.S. Fleet Weather Facility

U.S. Naval Station

San Diego, California

1 Commanding Officer

U.S. Navy Air Development Center

Johnsville, Pennsylvania

Attn: NADC Library

1 Superintendent

U.S. Naval Academy

Annapolis, Maryland

2 Department of Meteorology \& Oceanography

U.S. Naval Postgraduate School

Monterey, California

1 Commanding Officer

U.S. Naval Underwater Sound Laboratory

New London, Conne cticut

1 Commanding officer

U.S. Navy Mine Defense Laboratory

Panama City, Florida 
1 Commanding officer

U.S. Fleet Weather Central

Department of the Navy

Washington, D.C.

2 Officer-in-Charge

U.S. Fleet Numerical Weather Facility

U.S. Naval Postgraduate School

Monterey, California

\section{Air Force}

I Hdqtrs., Air Weather Service (AWSS/TIPD)

U.S. Air Force

Scott Air Force Base, Illinois

1 ARCRL (CRZF)

L. G. Hanscom Field

Bedford, Massachusetts

Army

1 Army Research Office

Office of the Chief of $R$ \& D

Department of the Army

Washington, D.C.

1 U.S. Army Beach Erosion Board 5201 Little Falls Road, N.W. Washington, D.C.

1 Army Research Office

Washington, D.C.

Attn: Environmental Sciences Division

OTHER U.S . GOVERIIMENT AGENCIES

20 Defense Documentation Center

Cameron Station

Alexandria, Virginia

2 National Research Council

2101 Constitution Avenue, N.W.

Washington, D.C.

Attn: Committee on Undersea Warfare

Attn: Committee on Oceanography

1 Laboratory Director

California Current Resources Laboratory Bureau of Commercial Fisheries

P.0. Box 271

La Jolla, California
1 Commandant (OSR-2)

U.S. Coast: Guard

Washington, D.C.

1 Commanding Officer

Coast Guard Oceanographic Unit

Bldg. 159, Navy Yard Annex

Washington, D.C.

1 Director

Coast \& Geodetic Survey

U.S. Department of Commerce

Washington, D.C.

Attn: Office of Oceanography

1. Geological Division

Marine Geology Unit

U.S. Geological Survey

Washington, D.C.

1 Director of Meteorological Research

U.S. Weather Bureau

Washington, D.C.

1 Director

U.S. Army Engineers Waterways Experiment Station

Vicksburg, Mississippi

Attn: Research Center Library

1 Laboratory Director

Bureau of Commercial Fisheries

Biological Laboratory

450-B Jordan Hall

Stanford, California

1 Bureau of Commercial Fisheries

U.S. Fish \& Wildlife Service

Post Office Box 3830

Honolulu 12, Hawaii

1 Attn: Iibrarian

1 Laboratory Director

Biological Laboratory

Bureau of Commercial Fisheries

P. 0. Box 3098, Fort Crockett

Galveston, Texas

1 Laboratory Director

Biological Laboratory, Auke Bay

Bureau of Commercial Fisheries

P.0. Box 1155

Juneau, Alaska 
1 Laboratory Director

Biological Laboratory

Bureau of Commercial Fisheries

P. 0. Box 6

Woods Hole, Massachusetts

1 Laboratory Director

Biological Laboratory

Bureau of Commercial Fisheries

P. 0. Box 280

Brunswick, Georgia

1 Laboratory Director

Tuna Resources Laboratory

Bureau of Commercial Fisheries

P. O. Box 271

La Jolla, California 92038

1 Bureau of Sport Fisheries \& Wildlife

U.S. Fish and Wildlife Service

Sandy Hook Marine Laboratory

P.O. Box 428

Highlands, New Jersey

Attn: Librarian

1 Director

National Oceanographic Data Center

Washington, D.C.

2 Defence Research Member

Canadian Joint Staff

2450 Massachusetts Avenue, N.W.

. Washington, D.C.

2 Library, U.S. Weather Bureau

Washington, D.C.

1 Director, Biological Laboratory Bureau of Commercial Fisheries Navy Yard Annex, Building 74 Washington, D.C.

1 Director, Bureau of Commercial Fisheries

U.S. Fish \& Wildlife Service

Department of Interior

Washington, D.C.
1 Dr. Gene A. Rusnak

U.S. Geological Survey

Marine Geology and Hydrology

345 Middlefield Road

Menlo Park, California

1 Dr. John S. Schlee

U.S. Geological Survey

c/o Woods Hole Oceanographic

Institution

Woods Hole, Massachusetts

1 Chief of Scientific \& Technical

Publication Staff

Office of Director

U.S. Coast \& Geodetic Survey

Mailing Code $\mathrm{C}-\mathrm{I2}$

Washington, D.C.

1 Dr. I. E. Wallen, Assistant Director, Oceanography Museum of Natural History Smithsonian Institution

Washington, D.C.

1 Bureau of Commercial Fisheries

Biological Laboratorv. Oceanography

2725 Montlake Boulevard East.

Seattle, Washington 98102

1 Chief, Marine Science Center

Coast \& Geodetic Survey

U.S. Department of Commerce

Lake Union Base

1801 Fairview Avenue East

Seattle, Washington 98102

$1 \mathrm{Mr}$. Henry D. Simmons, Chief

Estuaries Section

Waterways Experiment Station

Corps of Engineers

Vicksburg, Mississippi

\section{RESEARCH LABORATORIES}

2 Director

Woods Hole Oceanographic Institution

Woods Hole, Massachusetts

3 Project Officer

Laboratory of Oceanography

Woods Hole, Massachusetts 
1 Director

Narragansett Marine Laboratory

University of Rhode Island

Kingston, Rhode Island

1 Bingham Oceanographic Laboratories

Yale University

New Haven, Connecticut

1 Gulf Coast Research Laboratory

Ocean Springs, Mississippi

Attn: Librarian

1 Chairman, Department of

Meteorology \& Oceanography

New York University

New York, New York

1 Director

Lamont Geological Observatory

Columbia University

Palisades, New York

1 Director

Hudson Laboratories

145 Palisade Street

Dobbs Ferry, New York

1 Great Lakes Research Division

Institute of Science \& Technology

University of Michigan

Ann Arbor, Michigan

1 Attn: Dr. John C. Ayers

I Dr. Harold Haskins

Rutgers University

New Brunswick, New Jersey

1 Director

Chesapeake Bay Institute

Johns Hopkins University

Baltimore, Maryland

1 Mail No. 353

The Martin Company

Baltimore 3, Maryland

Attn: J. D. Pierson

1 Director, Marine Laboratory

University of Miami

\#I Rickenbacker Causeway

Miami, Florida 33149
1 Lieutenant Nestor L: L: Granelli

Montevideo 459

Buenos Aires, Argentint

2 Head, Department of Oceanography \& Meteorology

Texas A\&M University

College Station, Texas

1 Director

Scripps Institution of Oceanography

Ia Jolla, California

1. Allan Hancock Foundation

University Park

Los Angeles 7, Càlifornia

1 Head, Department of Oceanography Oregon State University.

Corvallis, Oregon

1 Director

Arctic Research Laboratory

Barrow, Alaska

1 Head, Department of Oceanography

University of Washington

Seattle, Washington

1 Geophysical Institute of the University of Alaska

College, Alaska

1 Director

Bermuda Biological station for Research

st. Georges, Bermuda

1 Technical Information Center, CU-201

Lockheed Missile and Space Divisior

3251 Hanover street

Palo Alto, California

1 University of Pittsburgh

Environmental Sanitation

Department of Public Health Practice

Graduate School of Public Health

Pittsburgh, Pennsylvania

1 Director

Hawaiian Marine Laboratory

University of Hawaii

Honolulu, Hawaii 
I Dr. F. B. Berger

General Precision Laboratory

Pleasantville, New York

1 President

Osservatorio Geofisico Sperimentale

Trieste, Italy

1 Department of Engineering

University of California

Berkeley, California

1 Dr. C. I. Beard

Boeing Scientific Research Laboratories

P. 0. Box 3981

Seattle, Washington

1 Applied Physics Laboratory

University of Washington

1013 NE Fortieth Street

Seattle, Washington

1 Documents Division - $\mathrm{ml}$

University of Illinois Library

Urbana, Illinois

1 Director

Ocean Research Institute

University of Tokyo

Tokyo, Japan

1 Marine Biological Association

of the United Kingdom

The Laboratory

Citadel Hill

Plymouth, England

1 Central Library

Lockheed-California Company

Dept. 72-25, Bldg. 63-1, Plant A-1

Burbank, California

1 New Zealand Oceanographic Institute Department of Scientific and Industrial Research

P. 0. Box 8009

Wellington, New Zealand

Attn: Librarian
1 Dr. J.A. Gast

Wildlife Building

Humboldt State College

Arcata, California

i 1 Department of Geodesy \& Geophysics

Cambridge University

Cambridge, England

1 American Biophysical Research Laboratory

P. 0. Box 552

Lansdale, Pennsylvania

1 Institute of Geophysics

University of Hawaii

Honolulu, Hawaii

1 Mr. Neil L. Brown

Bissett-Berman Corporation

G Street Pier

San Diego, California

1 Division of Engineering \& Applied Physics

Harvard University

Cambridge, Massachusetts

1 Director

Water Chemistry Department

Hydraulic Laboratory

University of Wisconsin

Madison, Wisconsin 53706

1 Department of Geology \& Geophysics Massachusetts Institute of Technology

Cambridge, Massachusetts

II Dr. Wilbur Marks

Oceanics, Inc.

Technical Industrial Park

Plainview, New York

1 Dr. Keith E. Chave

Marine Science Center

Lehigh University

Bethlehem, Pennsylvania 